
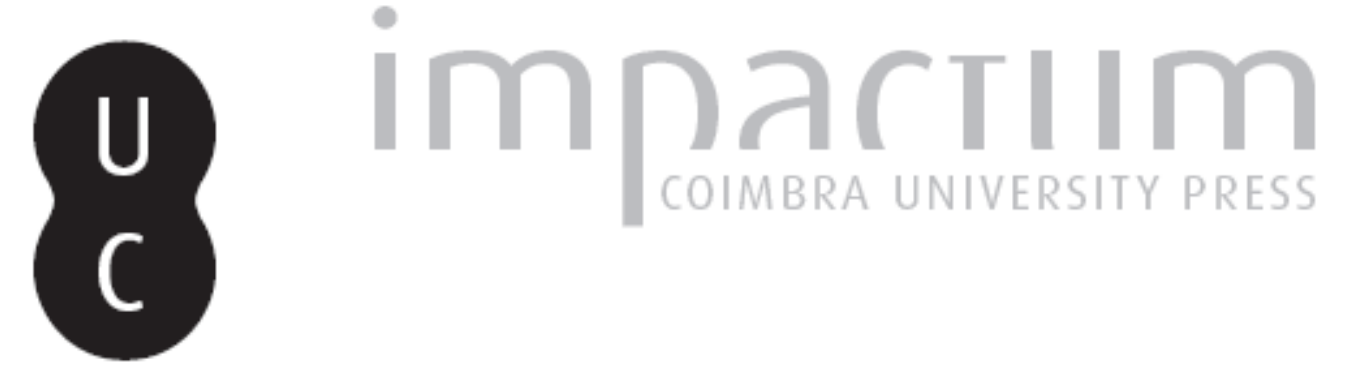

\title{
A Revolução Francesa no ensino da História em Portugal
}

Autor(es): $\quad$ Torgal, Luís Reis

Publicado por: Imprensa da Universidade de Coimbra

URL persistente:

URl:http://hdl.handle.net/10316.2/43794

DOI:

DOI:https://doi.org/10.14195/2183-8925_10_35

Accessed : $\quad$ 26-Apr-2023 02:08:19

A navegação consulta e descarregamento dos títulos inseridos nas Bibliotecas Digitais UC Digitalis, UC Pombalina e UC Impactum, pressupõem a aceitação plena e sem reservas dos Termos e Condições de Uso destas Bibliotecas Digitais, disponíveis em https://digitalis.uc.pt/pt-pt/termos.

Conforme exposto nos referidos Termos e Condições de Uso, o descarregamento de títulos de acesso restrito requer uma licença válida de autorização devendo o utilizador aceder ao(s) documento(s) a partir de um endereço de IP da instituição detentora da supramencionada licença.

Ao utilizador é apenas permitido o descarregamento para uso pessoal, pelo que o emprego do(s) título(s) descarregado(s) para outro fim, designadamente comercial, carece de autorização do respetivo autor ou editor da obra.

Na medida em que todas as obras da UC Digitalis se encontram protegidas pelo Código do Direito de Autor e Direitos Conexos e demais legislação aplicável, toda a cópia, parcial ou total, deste documento, nos casos em que é legalmente admitida, deverá conter ou fazer-se acompanhar por este aviso.

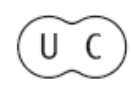


REVISTA DE HISTORIA DAS IDEIAS IO
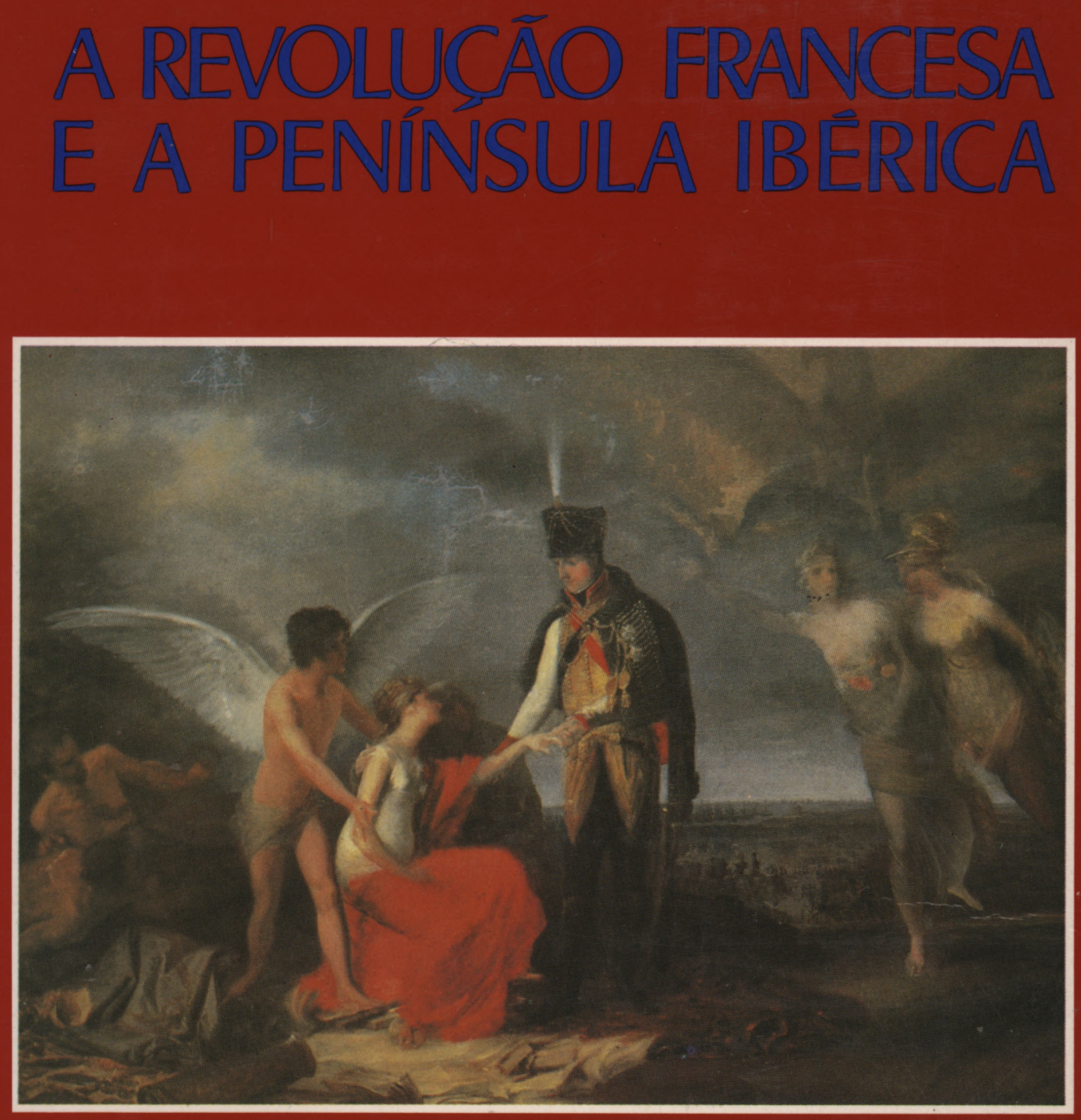

INSTITUTO DE HISTÖRIA E TEORIA DAS IDEIAS FACULDADE DE LETRAS 


\section{A REVOLUÇÃO FRANCESA NO ENSINO DA HISTÓRIA EM PORTUGAL **}

1. A história do ensino da História em Portugal está praticamente por fazer, podendo dizer-se que apenas se limita a um ou outro ensaio pioneiro e a algumas reflexões sugestivas no contexto da sociologia da educação ${ }^{(1)}$. Eis a razão por que resolvemos, no âmbito da cadeira de Teoria da História, levar a efeito, com um conjunto de alunos, uma primeira experiência nesse campo, cujos eventuais frutos estão ainda para surgir. Neste sentido, aproveitando a circunstância de se verificar em Coimbra o colóquio «A Revolução Francesa e a Península

* Faculdade de Letras da Universidade de Coimbra.

** Este estudo contou com a colaboração dos estudantes Maria da Graça de Jesus Arribança, Maria João Subtil Duarte Simões, Vanda Paula Esteves Carvalho, Joaquim Monteiro Brigas, João Paulo Avelãs Nunes, Ana Maria Mota Campos e Manuela Carvalho. Também nos cederam alguns elementos importantes os nossos colegas Maria Manuela Ribeiro, Isabel Nobre Vargues, Fernando Catroga e António Simões Rodrigues. Aproveitamos para esclarecer que não foi nosso objectivo passar em revista todas as reformas, programas e manuais referentes av ensino da História em Portugal. Compulsámos uma quantidade apreciável, mas não pretendemos mais do que apresentar aqui uma amostragem que nos pareceu significativa. Sobretudo procurámos surpreender os vectores essenciais desse ensino e, com base neles, interpretar a forma como foram abordados a Revolução Francesa e os fenómenos mais ou menos conexos.

(1) Vide Maria de Fátima Bivar, Ensino Primário e Ideologia, Lisboa, Seara Nova, 1975 (2: ed.), Maria Filomena Mónica, Educação e Sociedade no Portugal de Salazar, Lisboa, Presença-G.I.S., 1978, e Maria Carlos Radich, Temas de História em livros escolares, Porto, Afrontamento, 1979. Relativamente ao período salazarista, foram apresentadas algumas comunicações sobre o tema no Colóquio sobre o Estado Novo, recentemente realizado ( $O$ Estado Novo das origens ao fim da autarcia. 1926-1959, vol. II, Lisboa, Fragmentos, 1987). 
Ibérica», pensámos realizar uma primeira aproximação ao tema "A Revolução Francesa no ensino da História em Portugal», que nos propomos aqui abordar.

A questão central que colocámos é esta: Como foi encarada a Revclução Francesa ao longo do ensino da História em Portugal? A via de análise que seguimos consistiu na observação de um conjunto significativo e significante de manuais e de programas de História do ensino básico e, sobretudo, do ensino secundário $\left({ }^{2}\right)$, dado que foi sempre nesta fase que se estudou a História Universal. E quanto ao ensino superior? O Curso Superior de Letras, criado em Lisboa em 1858, está em parte estudado por alguns trabalhos de certo interesse, ainda que antigos, e conhece-se, pelo menos, não só as cadeiras que funcionavam e os seus respectivos professores, mas também alguns aspectos do seu ensino e até o conteúdo de algumas provas de concursos para o magistério, de onde se pode concluir qual o peso que o tema da Revolução Francesa ou outros conexos teriam $\left({ }^{3}\right)$. Quanto ao ensino da História das Faculdades de Letras - surgidas no âmbito da Universidade de Coimbra e da nova Universidade de Lisboa, em 1911, e da Universidade do Porto em 1919 (extinta 10 anos depois, vindo só a restaurar-se em 1962) - torna-se mais difícil, como é óbvio, levar a cabo uma análise directa do problema, devido geralmente à inexistência de manuais académicos. Para tal, recorremos à interpretação da estrutura curricular dos cursos, à consulta dos sumários escolares, embora apenas da Faculdade de Letras de Coimbra (esperamos que as outras faculdades tenham acautelado devidamente o arquivo desse importante material), bem como, o que nos pareceu um indicador essencial, à análise dos temas tratados nas dissertações de licenciatura.

(2) Utilizámos aqui, grosso modo, as designações de «ensino básico" e de "ensino secundário» que vigoraram até à recente "lei de bases» (Lei n. ${ }^{\circ} 46 / 86$, de 14 de Outubro), isto é, englobando na primeira o "ensino primário» e o ensino do "ciclo preparatório» e entendendo pela segunda o ensino seguinte, que recentemente se tornou «unificado» e se estende até ao $12 .^{\circ}$ ano. Estas designações - que agora encontraram uma nova dimensão - são, porém, relativamente novas. Se com as reformas de Veiga Simão, nos princípios dos anos 70, se distinguiram o "ensino primário», o "ciclo preparatório» (que então se iniciou) e o "ensino secundário", antes disso, e durante o período que praticamente começou com as reformas de Passos Manuel, apenas havia diferenciação entre o "ensino primário» e o «ensino secundário».

(3) Vide E. Adolfo Coelho, Le Cours Supérieur de Lettres, Paris-Lisboa, Aillaud, 1900, e, sobretudo, Manuel Busquets de Aguilar, O Curso Superior de Letras (1858-1911), Lisboa, 1939. 
A estas observações não pudemos, no entanto, deixar de acrescentar algumas pesquisas - as que nos foi possível efectuar - no campo da discussão pedagógico-científica do ensino da História, particularmente fértil nas últimas décadas do século XIX e nas primeiras do século XX. Elas permitiram-nos perceber não só o(s) sentido(s) do ensino existente, como também outros vectores programáticos propostos, que marcaram de facto algumas orientações fundamentais depois confirmadas.

Por outro lado, era também imprescindível a leitura de alguns indicadores de carácter bibliográfico: Que obras foram traduzidas em português, ou escritas de raiz em Portugal, scbre a Revolução Francesa? Que trabalhos surgiram relativos a fenómenos relacionados, tais como as invasões francesas e as revoluções e revoltas liberais portuguesas? $\mathrm{E}$ até: como é que esses fenómenos foram encarados por obras de história geral de grande divulgação? E não só nos interessava o tipo da bibliografia surgida, como também a sua data de publicação. Além disso, outra pesquisa nos pareceu importante nesta área: consultando algumas revistas científicas e culturais, encontrar-se-á nelas um número significativo de artigos referentes directa ou indirectamente à realidade revolucionária francesa? $\mathrm{E}$ ainda era muito pertinente interrogar-nos sobre questões histórico-culturais deste tipo: sendo as comemorações históricas um fenómeno fundamental de ligação entre o Passado e o Presente, em que História e Ideologia se interpenetram, será que os temas ligados, mediata ou imediatamente, à Revolução, foram alvo ou não dessas comemorações?

Finalmente, digamos que, como é evidente, não seria possível entender o problema complexo, que o tema central desta pesquisa supõe, sem partirmos das referências aos diversos condicionalismos ideológico-políticos, ideológico-culturais e ideológico-científicos que atravessam os dois últimos séculos. $O$ ensino da História. talvez mais do que aualquer outra área do ensino. é marcado pela influência das ideologias. Nem sempre, porém. elas se manifestam de forma directa. o que só é evidente no caso de existir uma ideologia claramente dominante e dnminadora. Sob formas indirectas e diluídas. as ideologias marcam também a dinâmica do ensino da História. Só que é então mais difícil detectá-las.

2. O ensino da História aparece inicialmente. no auadro escolar das Artes, em ligacão com a Retórica, e, na Universidade, no âmbito da faculdade de Teologia e das faculdades jurídicas. Em parte por isso foi difícil a sua libertação de uma forma literária-humanística, com significativo interesse pela Antigui- 
dáde (sobretudo pela "Antiguidade Clássica») e pela Idade Média, e de uma acepção «política» formal. E, por outro lado, se se pode aizer que a visão religiosa e "conservadora» do ensino da História vigente nas Artes vai cedendo o passo a uma visão, por assim dizer, social, laica e burguesa, desde que em fins de 1836 se instituem os liceus e se cria no seu âmbito uma cadeira de «Geografia, Cronolcgia e História» $\left({ }^{4}\right)$, ainda que as alterações mais evidentes só se tivessem verificado nas últimas décadas do sécule, já a situação nos parece diferente no que diz respeito à Universidade, onde, devido à própria estrutura da corporação $\left({ }^{5}\right)$, o ensino da História terá tido mais dificuldade em romper com a sua linha tradicional. $O$ peso que nas faculdades teológica e jurídicas tiveram os estudos de Antiguidade e os estudos medievalistas, na perspectiva da história sagrada e da história dos direitos romano e português, acabaram, de alguma forma, por influenciar a cadência do ensino das Faculdades de Letras, sobretudo de Coimbra, que foi, no quadro da hierarquia universitária, sucedânea da Faculdade de Teologia, de onde, de resto, vieram alguns dos seus primeiros professores. Isto, apesar dos esforços no sentido de conceder ao seu ensino uma dinâmica que estivesse de acordo com as perspectivas culturais e sócio-políticas da jovem República, logo ultrapassada ou negada quando se começa a verificar o movimento no sentido do revigoramento das ideias tradicionalistas $\left({ }^{(}\right)$.

(4) Vide Aura Adão, A criação e instalação dos primeiros liceus portugueses. Organização administrativa e pedagógica, Oeiras, Fundacão Calouste Gulbenkian, 1982, sobretudo cap. III. Ver também Vasco Pulido Valente, $O$ Estado liberal $e$ o ensino. Os liceus portugueses (1834-1930), Lisboa, G.I.S., 1973.

(5) Apesar de se dever enquadrar na polémica republicana contra as instituições e os valores conservadores. não deixa de ser significativo o juízo de Sidónio Pais, lente de Matemática em Coimbra, numa oração de sapiência célebre realizada em Outubro de 1908: "Porém ciência e religião têm esferas separadas. Ambas têm um corpo de doutrinas, mas os conhecimentos científicos emanam só da razão e as verdades religiosas apoiam-se na revelação, que é uma palavra que não tem sentido em ciência. Nestas condições a Escola, para ser livre, tem de ser neutral em matéria religiosa.... Assim o parece ter compreendido o Estado português que não exerce influência religiosa, nem a deixa exercer, na maior parte dos seus estabelecimentos de instrução. Subsistem apenas duas excepções inexplicáveis: a primeira é na Escola primária, onde se ensina ainda a doutrina cristã, mas este ensino não é obrigatório para os alınos c':jos pais pertençam a outras religiões. A segunda é a Uni"rercidnde to roimbra" (Annuario da Universidade de Coimbra, 1908$10 n 9$ n XI.VI).

$\left.{ }^{(}\right)$Há que estudar com mais profundidade o ensino da História ro âmbito das faculdades de Teologia e Direito (antes de 1836, Cânones e Leis) da Universidade de Coimbra e, após 1911, no âmbito das facul- 


\section{A Revolução Francesa no Ensino da História}

No movimento de transformação do sentido da História há que contar especialmente $\mathrm{ccm}$ a influência exercida pelo Positivismo $\left({ }^{7}\right)$. Foi sua intenção integrar o ensino numa dinâmica scciológica, partindo de um pressuposto evolucionista, assente na «lei dos 3 estados». Numa concepção «historicista», o Passado surgia, assim, como elemento ao serviço da educação social do Presente e do Futuro. Ora, as concepções positivistas, ligadas geralmente a uma militância republicana, acabaram por ter

dades de Letras, matéria que será objecto de futuro trabalho e na qual estão a pesquisar, sob minha direccão e da Dr:" Ana Leonor Dias Pereira, as estudantes Ana Maria Mota Campos e Manuela Carvalho Por isso devem ser entendidas como provisórias as reflexões gerais que aqui deixámos e aquelas que acrescentamos mais à frente. De qualquer forma, julgamos, obviamente, que a nossa interpretacão não está longe da realidade. E certo que no campo da Teologia não deixou de se estudar história contemporânea - assim deveria acontecer, por exemplo, em 1902-1903, na disciplina de História Sagrada e Eclesiástica leccionada por J. Mendes dos Remédios, que seguia o Compendium Historiae Ecclesiasticae, de Franciscus Zeibert (1.: ed. 1884), cujo programa abrangia, pelo menos no domínio das intenções de ensino, o período " $\mathrm{Da}$ Revolução Francesa aos nossos dias" (Annuario da Universidade de Coimbra, 1902-1903, secção IV, pp. 3-11) - e é certo também que no campo do Direito se estudava a nossa realidade constitucional de um ponto de vista histórico. No entanto, não devemos também deixar de salientar que, no primeiro caso, partindo do princípio que na prática se chegava a abordar a temática contemporânea, ela era encarada obviamente na perspectiva da Igreja. Por outro lado, cremos que nos estudos histórico-jurídicos - e dizemo-lo baseados nas críticas que lhe são movidas no tempo por estudantes e antigos estudantes - se deveria ainda acentuar a importância do direito romano, bem como se deveriam relevar as nossas instituições medievais, entendidas como elementos essenciais na estruturação do direito constitucional cartista, então vigente. Quanto ao ensino nos primeiros decénios das faculdades dc Letras, não pudemos por enquanto analisar o que se passou em Lisboa e no Porto (de 1919 a 1929). Em Coimbra, julgamos que se verificou uma tendência, aliás natural no seio das instituições universitárias do tempo, para uma "história metódica» (dita depois, pejorativamente, "positivista"), embora se notassem também esforços no sentido de "actualizar" o seu ensino. As críticas que lhe foram movidas, acusando-a de prolongar o ensino da Faculdade de Teologia, e a sua defesa entusiasmada parecem provar essa "ambiguidade» (vide $A$ Faculdade de Letras da Universidade de Coimbra ao País, Coimbra, França Amado, 1919). E a verdade é que, passado o tempo republicano, em que na cadeira de História Moderna e Contemporânea, leccionada por Alves dos Santos e depois por Gonçalves Cerejeira, se leccionaram realmente tcmas de história contemporânea, logo após 1926 se abandonou o estudo desta área, ao mesmo tempo que só muito parcialmente se iria acompanhar a transformação da História no sentido de novos métodos e de novas temáticas.

(7) Ver sobretudo o artigo-síntese de Fernando Catroga, "Os inícios do Positivismo em Portugal. O seu significado político-social», Revista de História das Ideias, n. 1, Coimbra, 1977, pp. 287-394. 
efeitos institucionais depois da década de 70, não só na área do Curso Superior de Letras, onde eram leccionadas cadeiras de História, e mesmo na Universidade, como também no ensino liceal, através da utilização dos compêndios (é o caso do Manual de História Universal, do lente do Curso Superior de Letras Consiglieri Pedroso) $\left(^{8}\right)$, no âmbito das polémicas sobre o ensino da História do final do século passado e das primeiras décadas do presente, e ainda nas reformas dos seus programas depois da implantação da República $\left(^{(}\right)$.

Mas, nas referidas polémicas sobre o ensino da História (ou fora do contexto directo dessa discussão) e com incidências práticas no referido ensino, desenha-se ainda um grande movimento de cariz nacionalista de tendências diversas. Ele é assumido pelos próprios positivistas republicanos, desejosos de conhecer a «alma popular» e de promover mitos nacionais que conduziriam a nação ao encontro consigo própria e, assim, ao advento da república redentora. Daí a importância que na sua inteligência tiveram os Centenários, que correspondiam - no dizer de Teófilo Braga, referindo-se ao Centenário de Camões, realizado em 1880 - ao desejo de tirar «da maior tradição do nosso passado histórico o estímulo para um renascimento» $\left({ }^{10}\right)$.

Os tradicionalistas vão também naturalmente aprofundar o seu nacionalismo (ele fazia parte integrante do seu ideário), não só no âmbito dessas polémicas (11), como também, depois de instaurada a República, no contexto do movimento integralista nascente. A sua intenção era, porém, outra, bem diferente

(8) Z. Consiglieri Pedroso, Manual de Historia Universal, Paris, Guillard, Aillaud e C.: 1884. Anteriormente foi publicado um Compêndio de História Universal que constituiu uma espécie de 1.: edição. Do Manual houve depois várias reedições - a última que encontrámos foi a $5 .^{2}$, de 1896.

(9) Recordemos apenas duas peças fundamentais dessa polémica em dois momentos diferentes: a de Teixeira Bastos, que curiosamente representa uma acalorada discussão sobre o tema no seio da família positivista, pois a sua crítica dirige-se ao Compêndio de Consiglieri Pedroso (vide "O ensino da Historia nos Lyceus», Revista de Estudos Livres, Lisboa, 1884-85, pp. 388-405, e "Questão Litteraria. O ensino da Historia nos Lyceus e o Snr. Consiglieri Pedroso», pp. 506-516); e a de Adolfo Lima, $O$ ensino da "Historia». Comunicação feita perante a Sociedade de Estudos Pedagogicos de Lisboa na sessão de 8 de Abril de 1914, Lisboa, Guimarães e C." Editores, 1914.

(10) História das ideias republicanas em Portugal, Lisboa, Nova Livraria Internacional, 1880 , p. 356. Veja-se também, e sobretudo, Os Centenarios como syntese affectiva nas Sociedades modernas, Porto, Typ. de A. J. da Silva Teixeira. 1884.

(11) Vide Manvel Bento de Sousa, O Doutor Minerva (Critica do ensino em Portugal). Lisboa, 1894. Este texto saiu primeiro no jornal tradicionalista $O$ Portugal. 


\section{A Revolução Francesa no Ensino da História}

daquela que motivara os positivistas republicanos (embora o positivismo também marcasse o seu espaço ideclógico) - para eles a Tradição histórica portuguesa era a essência da «alma nacional», tradição essa que se começara a destruir com o «terramoto pombalino» e com as ideias liberais de proveniência estrangeira.

Noutro sector, o movimento cultural caracterizado pela designação de «Renascença Portuguesa» tomava posição contra e «desnacionalização» e sobretudo contra o «afrancesamento» da nossa civilização, ao mesmo tempo que propunha um ensino da História centrado em especial nos valores nacionais. Teixeira de Pascoaes dera o sinal de chamada, envolto em concepções saudosistas neo-românticas $\left({ }^{12}\right)$, e Jaime Cortesão (que não era ainda o historiador consagrado - ou o «poeta-historiador», no dizer de Romero Magalhães $\left({ }^{13}\right)$ - de anos mais tarde) clamava, em 1912, num artigo representativo das ideias da «Renascença», pela nacionalização do ensino da História, que teria, pois, como um dos objectivos essenciais «ensinar aos alunos quais sejam as qualidades mais lusitanas, os elementos racionais que contribuíram para a realização das nossas maiores empresas e da parte com que entrámos na civilização da humanidade» (14).

Entretanto, numa outra área, de preocupações mais científicas, numa perspectiva menos «nacionalista» mas com o objectivo de promoção científica nacional em ligação com instituições e concepções científicas estrangeiras, num sentido mais moderno, onde era marcante uma atitude antipositivista e um enquadramento teórico e historiosófico bebido em Benedetto Croce, em Henri Berr e até nas polémicas originadas pelo marxismo, Fidelino de Figueiredo levava a efeito um movimento nacional de desenvolvimento da História. Ele será responsável pela criação da «Sociedade Nacional de História» $\left({ }^{15}\right)$, pela edi-

(12) Na sua conferência O Espirito Lusitano ou o Saudosismo, Pascoaes afirmava muito expressivamente: "O alto clero sempre fiel a Roma, os altos políticos sempre fiéis a Paris, têm sido os obreiros da nossa desnacionalização, os inimigos do nosso espírito e, por isso, da nossa independência» (cit. por Jaime Cortesão, in "A Renascença Portuguesa e o ensino da História-Pátria», A Aguia, vol. $1^{\circ} .^{\circ}$ n..$^{\circ}$ 9, Porto, 1912, p. 73).

(13) Vide Joaquim Romero Magalhães, «No trilho de uma ambição: o poeta-historiador Jaime Cortesão (1910-1927)», Cidadania e História. Em homenagem a Jaime Cortesão, Cadernos da Revista de História Económica e Social, 6-7, Lisboa, Livraria Sá da Costa, 1985, pp. 27ss.

(14) Jaime Cortesão, art. e lug. cits., p. 77.

(15) Vide de Fidelino de Figueiredo, Programma da Sociedade Portuguesa de Estudos Historicos, Lisboa, 1911. Para entender a visão da História de Fidelino de Figueiredo é fundamental a leitura do seu 
ção de uma «Biblioteca de Estudos Históricos Nacionais» e pela publicação da Revista de História, a partir de 1912.

De resto, este movimento está ligado a outras iniciativas de cultura, que, antes e depois e em outros sectores intelectuais, promoviam os estudos nacionais - são os casos da Revista Lusitana, publicada desde 1887, e de $O$ Arqueólogo Português, com a direcção de José Leite de Vasconcelos, no âmbito da etnografia, do Arquivo Histórico Português, fundado em 1903 por Anselmo Braamcamp Freire, ou da Lusitânia - Revista de Estudos Portugueses, dirigida por Carolina Michaëlis de Vasconcelos, que surgiu em 1924, dedicada essencialmente aos estudos literários. Mas, como é sabido, as revistas culturais de sentido nacional, ou mesmo nacionalista, ligadas às mais diversas tendências ideológicas, reproduzem-se nas últimas décadas do século XIX e princípios do século XX: desde a Renascença, em que colaboram Teófilo e Antero, juntamente com Cesário Verde e Gonçalves Crespo, à Revista de Portugal, dirigida por Eça de Queiroz, até à Seara Nova, saída em 1921, passando pela Alma Nacional, pela «saudosista» Aguia, pela revista Pela Grei-em que colaboraram intelectuais de formação diversa, entre os quais os futuros seareiros - e pela integralista Nação Portuguesa. Ao grupo da Seara Nova aderiu, como é sabido, António Sérgio e será ele que irá marcar uma nova visão da História que, embora acentuando c significado dos valores nacionais, se procura desligar da «tradição histórica». Inserindo a História numa visão sociológica, analisa-a tendo como objectivo a criação de um processo transformativo e revolucionário da sociedade portuguesa, que visa finalidades democráticas e socialistas. Mas, o impacto do ensaísmo historiográfico e historiosófico de Sérgio afirma-se sobretudo, em posição marginal, já no contexto de outras situaçōes ideológico-políticas a que vamos de seguida aludir $\left({ }^{\mathbf{1 6}}\right)$.

Portanto, pode dizer-se que, acompanhando e enfrentando os momentos de crise da última fase do liberalismo português

opúsculo $O$ espirito historico, introdução à Biblioteca de Estudos Históricus Nacionais. Consultámos a 3.a edição, Lisboa, Livraria Clássica Editora, 1920.

(16) Sobre a concepção sergiana de História, vide Vasco de Magalhães-Vilhena, «Em torno do idealismo histórico-social de António Sérgio», e Olga de Freitas da Cunha Ferreira, "António Sérgio e os Integralistas", Revista de História das Ideias, n. ${ }^{\circ}$. António Sérgio, tomo I, respectivamente. pp. 167 ss. e 427 ss. Sobre a Seara Nova, ver Seara Nova. Antologia, organização. prefácio e notas de Sottomayor Cardia, Lisboa, Seara Nova, 1971-1972, 2 vols. Sobre as revistas referidas e sobre outras, para o nosso século, vide Clara Rocha, Revistas literárias do século XX, Lisboa, Imprensa Nacional - Casa da Moeda, 1985, e Daniel Pires, Dicionário das revistas literárias portuguesas do século $X X$, Lisboa, Contexto, 1986. 


\section{A Revolução Francesa no Ensino da História}

e de uma república instável, se ergue, geralmente à margem dos aparelhos políticos, um movimento de inteligência de cunho nacional e nacionalista, de diversas origens e acepções ideológicas, que - com intenções e objectivos diversos - apontava para o desenvolvimento dos estudos históricos portugueses e, na generalidade, para a promoção dos valores da nossa cultura originária. Deve, porém, dizer-se que esse movimento tem raízes mais longínquas. Ele assenta nas concepções românticas de um Garrett ou de um Herculano e teve concretizações diversas no campo da História, desde o movimento anti-iberista e nacionalista que surgiu à volta dos anos 60 e que levou à formação da Comissão $1 .^{\circ}$ de Dezembro, conjugando à sua roda homens representativos da oficialidade cultural portuguesa, como Herculano, Rebelo da Silva e Inocêncio Francisco da Silva, personalidades do aparelho político, como Anselmo José Braamcamp e Fontes Pereira de Melo, e mesmo velhos representantes do liberalismo de vanguarda, como José Estêvão ${ }^{\left({ }^{17}\right)}$, até a um nacionalismo português, inicialmente de articulação federalista ibérica e de tipo sociológico e socialista, do Oliveira Martins das décadas de 70-80 $\left.{ }^{(18}\right)$, passando pela historiografia de divulgação e de cunho popular de Pinheiro Chagas $\left({ }^{19}\right)$.

Com a «Revolução Nacional» de 1926 e, sobretudo, com a instauração do «Estado Novo», o nacionalismo vai aparecer com um cariz diverso. Radicado nas concepções integralistas e com ligações aos conceitos de uma «democracia cristã» adaptada ao circunstancialismo político português, marcado por uma influência cada vez mais significativa do fascismo, transforma-se num nacionalismo institucional e autoritário, que necessariamente teria de marcar o ensino da História. O texto do decreto $n$. ${ }^{\circ}$ 21.103, aparecido logo em 1932, é paradigmático: ele fazia pautar

(17) Vide Visconde Sanches de Baena, Fastos historicos da Comissão Central do $10^{\circ}$ de Dezembro ou o monumento historico aos restauradores de Portugal, Lisboa, 1885-1886, 2 vols. Veja-se o que sobre o tema referimos na nossa obra Ideologia política e teoria do Estado na Restauração, Coimbra, Biblioteca Geral da Universidade, 1981, vol. I, pp. 14 ss.

(18) Recorde-se, para além das suas clássicas obras de história, História da Civilização Ibérica e História de Portugal, editadas em 1879, o texto que publicou em 1873, Exame constitucional da sociedade portuguesa e a sua reorganização pelo Socialismo, bem como as suas peças históricas, como Afonso VI, ou a obra Os filhos de D. João I (1891), cuja publicação se iniciou na Revista de Portugal, de Eça de Queiroz.

(19) Em relação a Pinheiro Chagas lembre-se a sua publicação da História Alegre de Portugal (1880) e a sua colaboração na biblioteca "Educação Popular» com vários livros de História, entre os quais podemos referir Aljubarrota, O Marquez de Pombal, A Guerra Peninsular. 


\section{Revista de História das Ideias}

a sua pedagogia por um modelo caracterizadamente «nacionalista». Assim, numa concepção de história leccionada por decreto, determinava de forma explícita: «Todo o feito que significa esforço da Nação, desde o início da História Pátria até ao presente, deve ser exaltado como bom e digno» (art. 2. ${ }^{\circ}$ ). E depois: «Deve ser objecto de justificação e glorificação tudo quanto se tem feito, através dos oito séculos da História de Portugal, no sentido de fortalecer os seguintes factores fundamentais da vida social: a Família, como célula social; a Fé, como estímulo da expansão portuguesa por mares e continentes e elemento de unidade e solidariedade nacional; o Princípio da Autoridade, como elemento indispensável do progresso geral; a Firmeza do Governo, espinha dorsal da vida política do País; o Respeito da hierarquia, condição básica da cooperação dos valores; e a Cultura literária e científica» (art. $3^{\circ}$ ). $\mathrm{E}$, abrindo as portas à repressão cultural, fechava-se o circuito: «Tudo quanto, pelo contrário, tem sido elemento de dissolução nacional, de enfraquecimento da confiança no futuro, falta de gratidão para com os esforços dos antepassados, deve ser objecto de censura» (art. $\left.4^{\circ}\right)^{\circ}\left({ }^{20}\right)$.

$\mathrm{O}$ «Estado Novo» prolongou-se, como se sabe, por quase 50 anos. No entanto, seria incorrecto pensar que esta marca de nacionalismo institucional povoou sem vacilações o ensino da História em Portugal durante meio século. Em especial ao nível do ensino secundário verifica-se uma transformação significativa no pós-guerra. $\mathrm{Na}$ verdade, coincidindo com uma certa esperança dc abertura do país aos valores democráticos, que na realidade não se concretizou, em 1947-48 processa-se uma importante reforma do ensino, que denuncia alguma actualização de concepções pedagógico-didácticas, por influências europeias e americanas, mas também devido a um aprofundamento da leitura das nossas estruturas escolares $\left({ }^{21}\right)$. No campo do ensino da História, talvez devido à força que começa a ter uma historiografia influenciada pelas concepções dos Annales, que em Portugal nos aparece geralmente como marginal, mas revelando sobretudo a persistência renovada (numa perspectiva conservadora) das concepções básicas do Positivismo ${ }^{(22}$, a filosofia dos novos

(20) Cfr. Diário do Governo, 1." Série, 15 de Abril de 1932, p. 625. Vide a sua transcrição in História Contemporânea de Portugal, dir. de João de Medina, "A Ditadura: o 'Estado Novo'», t. II, Lisboa, Amigos do Livro, 1985, pp. 45 ss.

(21) Cfr. Decreto-Lei n. 35.507 de 17 de Setembro de 1947, Imprensa Nacional, Lisboa, 1947.

(22) Cfr. Programas das disciplinas do Ensino Liceal. Decreto $n .^{\circ} 37.112$, de 22 de Outubro de 1948, Lisboa, Imprensa Nacional, 1948. 


\section{A Revolução Francesa no Ensino da História}

programas insere-se numa visão essencialmente «social». Depois, apesar do reavivar de um nacionalismo imperialista durante a guerra colonial, verifica-se nos anos 60, período de crise do «Estado Novo», uma abertura ainda maior (dentro das limitações do isolamento português) às correntes da «nova história»e da «nova pedagogia», que, se se manifestam em situações de marginalidade, se concretizam também através das reformas de ensino dos anos 70, que salientam não só o sentido «social» da pedagogia da História - ao nível secundário, como ao nível primário e preparatório (ciclo então criado) - como o seu sentido «Estrutural».

Pode, pois, dizer-se que nas vésperas do 25 de Abril de 1974 se diluía a perspectiva nacionalista da História, aproximando-a cada vez mais de uma visão «social» e «cosmopolita». Enquanto isso, na Universidade, verificou-se igualmente uma abertura a novos temas e a novas concepções historiográficas, que foram penetrando - hesitantemente, é certo, e através de esforços pessoais isolados - nos anos 60 e 70, à medida que se verificavam os grandes movimentos de revolta estudantil de sentido internacionalista.

Após 74-para terminarmos este breve quadro contextual - verifica-se um surto de influência marxista, que acompanha os objectivos socialistas afirmados com veemência na primeira fase da revolução, o qual teve uma influência significativa ao nível escolar e ao nível do ensino da História. Depois de 78, no quadro de um processo de recessão política da revolução e de estabilização institucional, atenua-se a pressão mar-

O neo-positivismo nota-se mesmo na terminologia utilizada. Assim, justificando o programa, pode ler-se: «Estudar-se-ão as instituições (elemento estático) e os acontecimentos (elemento dinâmico), de cujos entrelaçamentos, acções e reacções sai o progresso, aquele condicionando estes, estes modificando aquelas» (p. 116). De qualquer forma, há aspectos muito interessantes e inovadores nestas linhas programáticas: a oposição declarada a uma história factualista e cronologista; 0 apelo a uma "história social» ( $\mathrm{O}$ ensino da História nos liceus deve assentar, de um modo geral, no estudo das transmutações sofridas pela sociedade e pelo homem, que dêem a conhecer ao aluno a génese c as características do mundo contemporâneo e os valores que dominam o seu espírito e a sua estrutura. Assim apontará os aspectos que representam as necessidades, as persistentes lutas, os conflitos dos povos e classes, as correntes económicas, as crenças, as crises morais, os movimentos religiosos....»); a acentuação das relações, embora não deterministas, "entre as realidades sociais e humanas e o mundo físico"; o significado atribuído no mundo contemporâneo ao industrialismo, ao "predomínio da burguesia» e à «importância crescente do proletariado»; a inovação pedagógica de uma aprendizagem prática, etc. (cfr., sobretudo, pp. 116-120). 


\section{Revista de História das Ideias}

xista e verifica-se uma influência mais vigorosa e directa das várias correntes da «História Nova», que a pouco e pouco tem transformado um panorama historiográfico e uma orientação metodológica de ensino da História marcados por concepções economicistas num quadro mais polifacetado, onde se verifica o avanço da história das mentalidades e o reavanço, embora pensado em perspectivas que se desejam diferentes, da história política. Por outro lado, se com a influência da «História Nova» a presença francesa, sempre fundamental no espaço cultural português, se tornou decisiva ao nível ideológico-científico, também é certo que se verificam indícios de uma certa tentativa de libertação, aliada às reacções contra uma história estruturalista que fez perder a «memória histórica nacional». Numa encruzilhada epistemológica da História, num período caracterizado por uma certa desnacionalização, perante uma crise de valores históricos nacionais, de novo parece quererem irromper, ainda que de forma pouco organizada, sentimentos e ideias que procuram acentuar as nossas realidades. $\mathrm{E}$ com eles está a ressurgir o interesse pela releitura da história portuguesa e pela revisão metodológica do seu ensino, como também há tentativas para fazer ressuscitar, de forma directa ou indirecta, as velhas e já gastas concepções tradicionalistas da sua interpretação $\left({ }^{23}\right)$.

3. O primeiro compêndio de História Universal que conhecemos, usado no ensino das Artes, deve-se ao professor de Retórica do respectivo Colégio de Coimbra, Jerónimo Soares Barbosa (1737-1816). Intitula-se Epitome Universae Historiae ab orbe condito ad Carolum Magnum e foi publicado em 1805, sendo reeditado em 1812 e em 1827. Não é mais do que a edição latina da $1 .^{a}$ parte da obra de Bossuet, Discours sur l'Histoire Universelle. Portanto, a História Universal leccionada não ultrapassava o século IX D.C., centrando-se, sobretudo, no estudo da Antiguidade. Todavia, o referido manual era complementado por uma «Introductio Ad Universam Geographiam», por uma «Introductio Ad Universam Chronologiam» e por uma «Epitome Lusitanae Historiae». Este epítome da História de Portugal, em certos reinados simples transcrição da obra bilin-

(23) Sobre alguns dos aspectos aqui considerados, vide os nossos ensaios: "Acerca da Universidade e do ensino da História», Boletim da Associação de Professores de História, n. 7 , Nov. de 1983, pp. 3 ss.; "O lugar da História, o lugar do Historiador, o lugar do professor de História», in O Estudo da História, Boletim da Associação de Professores de História, n. 2 (II série), 1986-87; e "História.... Que História? Algumas reflexões introdutórias à temática da história local e regional», Revista de História das Ideias, n. ${ }^{\circ}$ 9, Coimbra, 1987, pp. 843-867. 


\section{A Revolução Francesa no Ensino da História}

gue de António Pereira de Figueiredo Elogios dos Reis de Portugal (1785), estende-se até ao ano de 1800 e aí aparece uma simples referência à Revolução Francesa. A imagem apresentada era aquela que assumiam oficialmente os estados monárquicos da Europa face à França revolucionária. Tratara-se de um movimento em que multidões e facções exaltadas ( «turbae et factiones excitatae») se revoltaram e mataram o rei Luís XVI. Daí que os príncipes da Europa tivessem declarado guerra à França, não só para vingar a «santidade» do rei executado, mas também a dignidade de todos os príncipes, que assim fora violada $\left({ }^{24}\right)$.

A ideia veiculada aos alunos de Artes sobre a Revolução Francesa era, pois, a de uma concepção contra-revolucionária. Outrossim as primeiras obras a serem traduzidas para português sobre a Revolução têm essa característica - é o caso da obra do abade Barruel que, na versão portuguesa, tem o título História abreviada da perseguição, assassinato e do desterro do Clero francês durante a Revolução (Porto, 1795-96) ${ }^{(25}$ ).

As Invasões Francesas em Portugal, de 1807 a 1811, vão ser, no âmbito da extensão do processo revolucionário francês, ainda que a elas não aluda obviamente o manual de Barbosa, o facto mais abordado, quer em termos de historiografia, quer em termos de ideologia. Aliás, a primeira grande obra historiográfica sobre o tema, a História geral da invasão dos franceses em Portugal e da restauração deste reino, de José Acúrsio das Neves, foi logo publicada em cima do acontecimento, a partir do ano de 1810. Pode dizer-se, pois, que as invasões e a "Restauração de Portugal»-terminologia que fica a povoar a nossa memória histórica, relacionada na nossa sensibilidade com outro fenómeno de «Restauração», operado em 1640 - aparecem no horizonte mental português se não ligadas a uma ideia de cruzada contra a França revolucionária, que nos foi transmitida pelos escritores tradicionalistas, como Acúrsio ou Frei Fortunato de São Boaventura, pelo menos indissoluvelmente conectadas com um sentimento nacionalista.

4. A Revolução Francesa, entendida como fenómeno fundamental na história, como acontecimento libertador, difusor das ideias liberais e, assim, positivamente transformativo da

(24) Epitome Universae Historiae, Coimbra, 1812, p. 420.

(25) José Agostinho de Macedo, baseando-se directamente em Barruel. escrevia também a obra $O$ segredo revelado ou manifestação do systema dos pedreiros livres, $e$ illuminados, $e$ sua influencia na fatal Revolução Franceza: obra extrahida das Memorias para a Historia do Jacobinismo do Abade Barruel, 6 partes, Lisboa, 1809-1812. 
estrutura dos estados, só aparece em Portugal em concepções marginais, durante as últimas décadas do século XVIII e nas primeiras do século XIX, à medida que são lidos os seus principais teóricos e pré-teóricos, pois que, conhecida oficialmente, era, como se disse, só a história negra da Revolução, expressa especialmente por Barruel e, em sentido de crítica teórica à maneira inglesa, por Burke $\left({ }^{26}\right)$.

Em 1820 tem-se já uma nova ideia da Revolução. No entanto, não deixa de ser curioso o facto de não se ter esquecido a sua imagem sangrenta - ela é referida no discurso político dos vários liberais portugueses, que pretendem que a nossa revolução não caia nos excessos da Revolução Francesa $\left.{ }^{27}\right)$. De resto, se a retórica justificativa da Revolução de 1820 se baseia nos ideais liberais franceses, como não podia deixar de ser, fundamenta-se também, pelo menos no domínio dos argumentos, na leitura liberal das nossas instituições tradicionais. Daí a importância que foi conferida por alguns dos «regeneradores» - saliente-se o sentido histórico que o termo supõe - ao estudo e à compilação das leis portuguesas, processo que se operou no âmbito dos estudos de história do direito da Universidade pós-pombalina e da Academia das Ciências, com Pascoal de Melo Freire e João Pedro Ribeiro, para continuar por acção dos próprios futuros vintistas, como Fernandes Tomás e Borges Carneiro. Aliás, o Portugal Regenerado de Carneiro, que constitui a primeira e principal obra de fundamentação da Revolução de 20, move-se acima de tudo no espaço teórico jurídico-político português.

Portanto, pode dizer-se que, apesar de tudo, no domínio do ensino a Revolução Francesa não ocupou um espaço privilegiado depois de 20 . $\mathrm{Na}$ própria Universidade, instituição conservadora, foi inclusivamente muito difícil a penetração do es-

(26) Excertos das obras de Burke foram traduzidos logo em 1812 por José da Silva Lisboa: Extractos das Obras de Edmundo Burke, Rio de Janeiro, 1812, 2 tomos. Em 1822 aparece 2." edição desta obra em Lisboa.

(27) Por várias vezes deputados vintistas manifestamente liberais, embora de acentuação diversa, tomam posição contra os excessos da Revolução Francesa. Por exemplo o deputado Alexandre Morais Sarmento comparou a Revolução Francesa, utilizando uma imagem de Vergniaud, a Saturno devorando os seus próprios filhos (Diário das Cortes, t. V, sessão de 4 de Fevereiro de 1822, p. 76); noutro local o deputado Ferreira de Moura opõe-se à radicalização jacobina das assembleias de 1792 e 1793 e às posições assumidas por Bazire, Saint Just ou Buzot (D.C., t. VI, sessão de 23 de Maio de 1822, p. 258); Pereira do Carmo critica os excessos da Convenção (D.C., 2." legislatura, t. I, sessão de 9 de Janeiro de 1823, pp. 402 e 403). 


\section{A Revolução Francesa no Ensino da História}

tudo do novo direito constitucional português $\left({ }^{28}\right)$. O ensinosegundo cremos - mantinha-se essencialmente à margem da realidade revolucionária que atingira a Europa e, nomeadamente, Portugal.

Mesmo depois da implantação definitiva do liberalismo, em 1834, não parece ser maior a importância conferida à Revolução no quadro do nosso ensino da História e, sobretudo, do nosso imaginário mitificador de acontecimentos. É preciso não esquecer que, tirando 0 curto hiato resultante da Revolução de Setembro, estamos perante uma ordem constitucional cartista, que não se radicava essencialmente no espírito da Revolução Francesa, mas sim no da Restauração da Monarquia por Luís XVIII. E o certo é que inclusivamente nos setembristas, até em alguns dos mais radicais, não deixa de assomar uma imagem critastrófica da prática da Revolução da França $\left({ }^{29}\right)$. Pode dizer-se que o desejo de ordem que caracteriza de um modo geral a burguesia política portuguesa depois dos anos 40, e mesmo antes, e que prepara o movimento da «Regeneração» da década seguinte - registe-se a reutilização da palavra - não se coadunava com a mitificação de um movimento que, apesar de ter difundido princípios que até certo ponto estavam na base do seu ideário, lançara a França numa terrível luta interna. Não é por acaso que Garrett, um setembrista «ordeiro», publica a seguir a 1843 as Viagens na minha terra, onde evoca, a partir de um drama familiar que tem como pano de fundo os acontecimentos trágicos da guerra civil, a grandeza de Portugal presente na alma popular, em confronto com a situação de crise por que o país passava, crise que se verificava ao nível dos valores tradicionais e ao nível dos valores liberais.

(28) Cfr. da nossa autoria e de Isabel Nobre Vargues, $A$ Revolução de 1820 e a Instrução Pública, Porto, Paisagem, 1984, p. 173, nt. 1.

(29) Com efeito, se entre os setembristas «ordeiros» se detecta a imagem negativa da Revolução, como se pode verificar através do discurso de Pereira Derramado, com base na interpretação de Burke (Diário das Cortes, t. III, sessão de 27 de Set. de 1837, pp. 14-16), também ela aparece entre os setembristas exaltados, como Miguel António de Vasconcelos, embora em termos diferentes, pois ainda que constate a existência de uma violência revolucionária, também é certo que procura explicar os seus motivos. Referindo-se aos propalados perigos do monocameralismo, que defendia, afirma: "Muito se exageram os temores de que em Portugal se repitam as cenas da Revolução Francesa se não houver segunda Câmara, porque se julga que o povo é uma fera. Mas que pedia o povo quando se revolucionou a França? Pedia a cousa mais simples: ele queria a continuação dos três estados, mas que o estado do povo tivesse dois votos: comprimiram-no, ele rebentou como a pólvora e arrasou os outros estados. Quereremos nós fazer o mesmo? Nấo..... (Diário das Cortes, t. III, sessão de 29 de Set. de 1837, p. 48). 


\section{Revista de História das Ideias}

O sentimento de repulsa pelas guerras fratricidas e a esperança na ressurreição do país assente nos valores portugueses, em conjugação com os autênticos valores liberais e cristãos, serão depois sucessivamente assumidos por um liberalismo «regenerador» e virão mesmo a ser aproveitados por uma ideologia nacionalista, que firmava os seus projectos de reforma na defesa da tradição nacional, da unidade e da «ordem». Daí a importância que as Viagens e Garrett tiveram, quer no âmbito das considerações integralistas, quer no «Estado Novo» $\left.{ }^{(30}\right)$. Foram estes ingredientes que constituíram, de resto, a imagem essencialmente retida pela "historiografia de regime» do salazarismo, que ainda hoje encontra traços de sobrevivência $\left.{ }^{(31}\right)$.

Igualmente interessante é conhecer o significado e a fortuna do romance do escritor «liberal regenerador», que participara nas guerras civis da década de 40, António de Oliveira da Silva Gaio, Mário, Episódios das lutas civis portuguesas de 1820-1834, cuja primeira edição é de 1868. Também ali aos ódios das lutas fratricidas, manifestados sobretudo pelos miguelistas - e mesmo, episodicamente, pelos estudantes das sociedades secretas que mataram os lentes absolutistas em Condeixa - opõe o sentimento de bondade e de solidariedade, que era atributo do povo simples e dos verdadeiros constitucionais, que aliavam os princípios do liberalismo aos autênticos valores da caridade cristã. Este carácter «consensual» da mensagem - apesar do anti-miguelismo -, que pode ao mesmo tempo servir os interesses «ordeiros» e os ideais «liberais», e algumas virtudes literárias do romance (ainda há pouco salientadas) ${ }^{32}$ ), serão responsáveis pela divulgação da obra, que tem tido mais de uma dezena de edições, ao longo da Monarquia Constitucional, do «Estado Novo» e do período posterior ao 25 de Abril $\left({ }^{33}\right)$.

(30) Vide, da nossa autoria e de Amadeu de Carvalho Homem, "Ideologia Salazarista e 'cultura popular' - análise da biblioteca de uma Casa do Povo", Análise Social, vol. XVIII, 1982, pp. 1451 ss.

(31) Note-se que numa obra de divulgação da História de Portugal para crianças, recentemente publicada. $A$ minha primeira História de Portugal, de António Manuel Couto Viana, com ilustrações de Fernando Bento, a única imagem que se retém da primeira fase do liberalismo é a luta fratricida ("Irmão contra irmão») à qual se opõe o desejo de "paz" e de "unidade». e o "progresso», que se verifica na "Regeneração" (ob. cit., Lisboa, Verbo, 1984, pp. 32-35).

(32) Vide a introdução de Joaquim Ferreira à última edição da obra (Porto, Porto Editora, 1984).

(33) Para além da 1.: edição, de 1868, da Imprensa Nacional, contámos (sem procurarmos ser exaustivos) mais duas ediçóes durante a Monarquia Constitucional, uma de 1877 (da Imprensa Académica, com uma apresentação de Tomás Ribeiro) e outra de 1901, nove edições de 1934 a 1974, e duas mais recentes, de 1981 (que reproduz a apresentação 


\section{A Revolução Francesa no Ensino da História}

5. Voltando propriamente ao ensino escolar da História, pode dizer-se que, depois da criação dos liceus, se multiplicam os manuais de História Universal. São os casos dos compêndios de João Félix Pereira e de João António de Sousa Dória, que para além de serem médicos foram professores de «Geografia, Cronologia e História» nos liceus nacionais, e de Manuel Francisco de Medeiros Botelho, que frequentou a Faculdade de Matemática e veio a ocupar o lugar de inspector da instrução primária $\left({ }^{34}\right)$. Detenhamo-nos apenas no manual de Sousa Dória, o mais divulgado de todos, pois, desde a 1. ${ }^{a}$ edição, em 1844 , teve sucessivamente várias outras, até, pelo menos, 1872.

A importância conferida à Antiguidade é um facto relevante. Basta que se diga que a ela dedicou o autor todo um volume, de 188 páginas (na 7. ${ }^{a}$ edição, de 1867), ao passo que à História Universal da Idade Média e, lato sensu, da Idade Moderna, portanto desde o fim do século $\mathrm{V}$ até meados do século XIX, destinou somente 43 páginas (na 8. a edição, de 1872) do volume II do compêndio, dedicando as cerca de 100 páginas seguintes à História de Portugal. Portanto, os acontecimentos contemporâneos e mesmo os sucessos do mundo moderno são, por assim dizer, subalternizados - à «História Moderna», em sentido lato, não chega a dedicar 20 páginas, destinando apenas 8 aos acontecimentos verificados depois da Revolução Francesa. Quanto à História de Portugal do século XIX, apenas lhe são destinadas 9 páginas. Relativamente ao conteúdo, poucas conclusões se podem tirar. Num texto muito conciso, onde a história se reduz à compilação de acontecimentos, os sucessos da Revolução Francesa são descritos com grande superficialidade e também - diga-se - sem nítidos juízos de valor. No entanto, a imagem que fica não tem, de forma alguma, uma configuração positiva. Vejamos o passo mais significativo do texto de Dória, após se ter referido à crise da França nas vésperas da Revolução e à inépcia política de Luís XVI, apesar de considerar as suas «muitas virtudes»: «Nestas circunstâncias - dizia o autor - os sectários das ideias progressistas julgaram que só podiam livrar a França do abismo, fazendo uma revolução:

de Tomás Ribeiro) e de 1984 (com a referida introdução de Joaquim Ferreira).

(34) Cfr. J. Félix Pereira, Compendio de Historia Universal para uso dos lyceus, Lisboa, Typ. de A. J. Germano, 1869, 3 tomos; J. A. de Sousa Dória, Compendio de Historia para uso das escolas, Coimbra, Imprensa da Universidade, 1844 (surgiram depois várias outras edições); M. F. de Medeiros Botelho, Curso de Historia Universal, Coimbra, Imprensa da Universidade, 1878. Estes autores publicaram também outras obras de carácter compendiário. 


\section{Revista de História das Ideias}

fizeram-na. A realeza foi abolida na França (1792) e a cabeça de Luís XVI caiu debaixo do cutelo revolucionário». Os excessos revolucionários são pois a marca que mais caracteriza, ou só caracteriza, o grande acontecimento. De tal modo que foram esses excessos a causa de se vir a sentir a necessidade de uma autoridade, Napoleão, que acabou por querer dcminar o mundo: «No meio destas agitações facciosas e das crises contínuas em que se achava a França, - pode ler-se no compêndio - fazia-se mister uma mão vigorosa, para dirigir e sustentar esta nação». Bonaparte - essa «mão vigorosa» - aparece, assim, aos olhos do compendiarista, como uma personagem lendária, misto de grande militar e de imperador despótico ${ }^{(35}$ ). Aliás, pode dizer-se em parêntesis que os livros ou artigos sobre Napoleão, traduções ou textos originais, estudos de história ou simples obras romanceadas, constituem um núcleo significativo do espaço bibliográfico português sobre esta época $\left({ }^{36}\right)$.

Mas, se a imagem que Dória dava aos estudantes de História sobre a Revolução Francesa não era, de modo algum, positiva, que ideia nos apresenta da realidade liberal de 20 e dos acontecimentos que a antecedem? Aqui as coisas são consideradas de modo diferente, apesar do carácter telegramático dos textos. Gomes Freire e os seus companheiros são apresentados como «as primeiras vítimas da liberdade portuguesa»; a Revolução de 1820 é entendida como «uma grande mudança», que fez face à situação de crise do país e resultou de um movimento, inspirado nas ideias liberais, que procurou contrariar o "estado violento» criado sobretudo por Beresford; Fernandes Tomás é elogiado como «exímio patriota» e são também tidos como "patriotas» Sepúlveda e os autores do levantamento militar do Porto; dos efeitos positivos da Revolução apenas quis registar a extinção do Santo Ofício $\left.{ }^{(37}\right)$.

Poder-se-á dizer, portanto, que, mais do que as ideias concretas sobre a Revolução Francesa e os acontecimentos portugueses com ela relacionados, o que se torna mais evidente é o peso conferido ao mundo antigo e um pouco à Idade Média, em confronto com o menor significado concedido às realidades da vida moderna e contemporânea. De tal forma isso era notório que, nos primeiros programas de História, o seu ensino parava na época medieval. Assim acontece ainda com o pro-

(35) J. A. de Sousa Dória, Compendio de Historia para uso das escholas, vol. II, Coimbra, Augusto Orcel, 1872 (8:" ed.), pp. 35-37.

(36) Podemos dizer que encontrámos - numa simples consulta de catálogo efectuada na Biblioteca Geral da Universidade de Coimbra, que apenas terá o valor de amostragem - algumas dezenas de títulos.

(37) Ob. e vol. cits., pp. 140-41. 


\section{A Revolução Francesa no Ensino da História}

grama de $1872\left({ }^{38}\right)$. Este facto originou até críticas veementes, como aquela que em 1876 Ramalho Ortigão dirigia ao Ministro do Reino: "As noções de história ministradas segundo o programa oficial do ensino - escrevia ele - terminam com a Idade Média. A Renascença, berço de todas as modernas instituições sociais, ficou no tinteiro da comissão legisladora. Para o fim do ensino supõe-se não existirem factos subsequentes, os mais importantes para o homem actual: a criação da burguesia, o advento do constitucionalismo inglês, a independência dos Estados Unidos, a Convenção francesa, a queda das antigas monarquias, dos privilégios da nobreza e do clero, a definição dos direitos do homem, etc. E, no entanto, desconhecendo inteiramente as vistas gerais, e compreensão harmónica do conjunto, todo o aluno de história tem pretensões veementes a saber a vida íntima de Nero e de toda a sua família, a de Calígula, do seu cavalo e de todos os seus vícios, bem como os nomes de todos os filhos bastardos dos reis portugueses e das suas respectivas mães» $\left({ }^{39}\right)$.

6. Em breve, porém, os programas vão-se transformando e incluindo matérias referentes ao mundo moderno e contemporâneo, à medida que também o ensino da História vai adquirindo maior importância, estendendo-se por mais anos. Nomeadamente a linguagem científica modifica-se e da simples nomeação dos factos passa-se, a partir dos anos 80, a uma interpretação causalística. Assim, em 1886 deparamos com a unidade de ensino «Causas e consequências da Revolução» e este tipo de análise passará a povoar o horizonte das reflexões pedagógicas da História até quase aos nossos dias $\left({ }^{40}\right)$.

Os anos 80-90, e já mesmo os anos 70, vão conhecer, de resto, como já aludimos atrás, um grande movimento de ideias

(38) Programmas para os Lyceus Nacionaes coordenados pela Junta Consultiva de Instrucção Publica e mandados adoptar por Portaria de 5 de Outubro de 1872, Lisboa, Imprensa Nacional, 1875, pp. 36-37.

(39) As Farpas, t. XV, 1876-1882, ed. de Lisboa, Livraria Clássica Editora. 1963, pp. 33-34.

(40) Em 1880 o programa do $4 .^{\circ}$ ano dos liceus incluía a seguinte rubrica: "A revolução francesa de 1789; a república e o império em França. Reacção contra as ideias liberais em França depois de 1815" (Programmas para o ensino nos institutos secundarios approvados por decreto de 14 de Out"bro de 1880. Edicão official, Lisboa, Imprensa Nacional, 1880, p. 9). No programa de 1886 do mesmo $4 .^{\circ}$ ano aparece a mesma rubrica com o seguinte texto: "A revolução francesa de 1789; a república; o consulado e o império. Causas e consequências desta revolucão. Reaccão contra as ideias liberais em França depois de 1815" (Programmas para o ensino nos lyceus approvados por Portaria de 16 de Novembro de 1886. Edição official, Lisboa, Imprensa Nacional, 1886, p. 50). 
por aç̧ão da conjugação do Positivismo e do avanço das ideias republicanas. Pode dizer-se que só então - na sequência das concepções que se afirmam, embora de forma embrionária, pelos anos 40, no contexto da Revolução Francesa de 48, e agora em certa consonância com a renovação da Comuna de Paris, em 1871 - é que verdadeiramente se reabilitam os ideais «jacobinos» e a "grande Revolução Francesa». Como exemplo significativo disso veja-se o texto de Teófilo Braga História das Ideias republicanas em Portugal (Lisboa, 1880) (41). Essa altura também é assinalada, com referência à França, pela grande divulgação da literatura social, nomeadamente de Victor Hugo, cujas obras mais significativas nesse âmbito, como Les Misérables (1862) e Quatre-vingt-treize (1873), são objecto de sucessivas traduções $\left({ }^{42}\right)$. E então igualmente que se inicia o grande movimento tradutório de obras sobre a Revolução Francesa, que já tivera, porém, nas décadas de 40-50, alguma produção significativa, com a versão portuguesa das obras de Thiers e Lamartine $\left({ }^{43}\right)$. Assim, em 1875 deparamos com a tradução de uma História da Revolução Francesa de 1789 de Ernest Hamel, realizada por Consiglieri Pedroso e Carrilho Videira ${ }^{(44)}$, de Os sol-

(41) Cfr. cap. II, «As ideias francesas (jacobinismo)».

(42) Na verdade, a obra Os Miseráveis foi traduzida logo em 1862 (tradução de F.F. da Silva Vieira, Lisboa, F. Gonçalves Lopes, 1862), conhecendo, como acima se disse, diversas traduções. Em 1875 começou a ser traduzida a obra Noventa e três pela imprensa periódica democrática (cfr. A Democracia, Elvas, 5 de Maio de 1875), aparecendo em 86 a primeira versão portuguesa completa (tradução de Maximiano de Lemos Junior, Porto, Lemos e C. ${ }^{a}$ Editores, 1886-1887, 2 vols.), à qual se sucederam outras edições. Ver, sobre o movimento tradutório português de Hugo, A. A. Gonçalves Rodrigues, Victor Hugo em Portugal, Lisboa, Biblioteca Nacional, 1985. Ver também João Medina, Aspectos da Hugolatria portuguesa: a projecção política de Victor Hugo em Portugal, separata das Actas do Colóquio "Victor Hugo e Portugal», Faculdade de Letras do Porto, 1987.

(43) De Thiers, Historia da Revolução Franceza, Lisboa, Typ. Lusitana, 1841, 6 tomos (houve outra edição em 1844) e Historia do Consulado e do Imperio, Lisboa, Imprensa da Gazeta dos Tribunais, 1845-1852. De Lamartine, Historia dos Girondinos, trad. de Duarte de Almeida e Araújo, Lisboa, Typ. Universal, 1854.

(44) Ernesto Hamel, Historia da Revólução Franceza, Biblioteca Historico-Cientifica - Biblioteca Republicana Democratica, Lisboa, Livraria Internacional, 1875. É interessante anotar que, no Prólogo, Consiglieri Pedroso justifica esta tradução no significado que tem a Revoção Francesa ("A tradição revolucionária é o nosso património; o seu decálogo são os nossos evangelhos») e na importância cultural que tem para o povo português dar a conhecer a sua verdadeira imagem. E, concretamente. explicava: "Bem triste deve ser a ideia que fazem do maior movimento dos tempos modernos, aqueles que não podendo ler as obras originais. só tenham dele conhecimento pelas declarações de 


\section{A Revolução Francesa no Ensino da História}

dados da Revolução de Michelet em 1889 (45) e, nas vésperas da República, ou logo depois da sua institucionalização, irão surgir as traduções das obras de Alfred Nicolas Rambaud (1908), de Louis Blanc (1910), de Mignet (1911), de Edgard Quinet (1912) $\left({ }^{46}\right)$, ou até simples «recapitulações» por autores republicanos, como é o caso da obra do General Celestino de Sousa ( ${ }^{47}$ ). Entretanto, em 1889, a Revolução Francesa será lembrada ao nível da imprensa e de algumas comemorações $\left({ }^{48}\right)$.

Mas não é só a Revolução Francesa que vai merecer o interesse dos historiadores, políticos e homens de cultura. Data desta altura, como é sabido, a afirmação dos grandes mitos históricos republicanos, que se desenvolvem sobretudo à roda dos centenários de Camões e Pombal. Também a Revolução de 1820 e os seus heróis, sobretudo Fernandes Tomás, são apresentados como exemplos a seguir, do mesmo modo que a Revolução de 1383 e João das Regras ou a Revolução de 1640 e João Pinto Ribeiro. Aparece assim a ideia do «herói popular», portador avant la lettre do espírito liberal e democrático. Por sua vez, a historiografia, republicana ou não, interessa-se pelo que se passa no século XIX português. $\mathrm{Na}$ verdade, é então que se publicam as obras clássicas sobre a nossa realidade oitocentista: em 1870 Luís Augusto Rebelo da Silva dava à luz a cbra biográfica Varões ilustres das três épocas constitucionais; em 1881 aparece a $1 .^{\mathrm{a}}$ edição de Portugal Contemporâneo, de Oliveira Martins; em 1886-89 o republicano José de Arriaga

Lamartine na História dos Girondinos, pelo falso critério histórico de Thiers, ou pelas deturpações de Alexandre Dumas na História de Luis $X V I$, únicos livros que se acham vertidos em português, segundo nos parece. Eis a justificação do nosso empenho".

(45) Os soldados da Revolução, versão prefaciada e anotada por Fernando Leal, Lisboa, 1889.

(46) Alfred Nicolas Rambaud, Historia da Revolucão Franceza, trad. de João Barreira, Lisboa, Livraria Ferreira, 1908: Louis Blanc, Historia da Revolução Franceza. Lisboa. João Romano Torres. 1910 (2 vols.); François Avguste Marie Mignet, Historia da Revolução Franceza, Lisboa, Casa Alfredo David, 1911 (2 vols.); Edgard Quinet, Historia da Revolucão Franceza, trad. de Domingos Guimarães, Porto, Magalhães e Moniz, 1912.

(47) A Revolução Franceza (n'um só volumie). Recapitulação pelo General Celestino de Sousa, Lisboa, Livraria Internacional, 1911. A obra tinha como epígrafe o texto: "Digam o que disserem, a Revolução francesa é o maior passo que a humanidade tem dado, depois do advento de Cristo".

(48) Veja-se neste volume as comunicações de João Lourenço Roque, Ecos do 1. Centenário da Revolução Francesa na imprensa regional de Coimbra. e de Isilda Braga da Costa, Salvador Magalhães Mota e José Paulo Moura, A comemoração do Centenário da Revolução Francesa na imprensa diária portuense. 
publica a História da Revolução Portuguesa de 1820, em 92 a História da Revolução de Setembro, para em 1911 vir a editar Os últimos 60 anos da Monarquia - causas da Revolução de 5 de Outubro de 1910; outro republicano, Latino Coelho, lança, de 1874 a 1891, a História política e militar de Portugal desde os fins do século XVIII até 1814; Luz Soriano, de 1866 a 1890, editou a sua volumosa História da guerra civil e do estabelecimento do governo parlamentar em Portugal; Clemente José dos Santos, em 1883-1891, dava à estampa os Documentos para a história das Cortes Gerais da Nação Portuguesa e, em 1887, as Estatísticas e biografias parlamentares portuguesas; em 1891-92, Tomás Ribeiro publicava a História da legislação liberal portuguesa; em 1901 António Tavares de Albuquerque fazia sair o primeiro tomo do Indice alfabético e remissivo dos trabalhos parlamentares das Cortes Gerais.

Neste contexto, a Revolução Francesa acabaria também, como é lógico, por ser mais positivamente valorizada em termos de ensino. O Manual de História Universal de Consiglieri Pedroso, que teve larga divulgação no ensino secundário, apesar das críticas de que foi alvo à direita e à esquerda $\left({ }^{49}\right)$, dedica à Revolução Francesa uma análise mais cuidada e polifacetada, que termina com esta síntese: «Em suma, a maior prova da necessidade histórica da revolução francesa está em que, apesar de todas as contra-revoluções e reacções que posteriormente se realizaram para destruir a sua obra, os princípios que ela proclamou, e as conquistas que levou a cabo na ordem material e moral, ainda hoje são a base em que assenta a sociedade contemporânea» $\left({ }^{50}\right)$.

Por sua vez, no Curso Superior de Letras, embora não tivéssemos analisado verdadeiramente as matérias de ensino ministradas, sabemos que se dedicava certa atenção ao estudo da Revolução Francesa e de outros processos revolucionários. Com efeito, pode verificar-se que, quando se realizou um concurso para a admissão de um lente de História Universal e Pátria, em 1878, um dos pontos a serem sorteados pelo candidato tinha o seguinte enunciado: "A revolução francesa realizou o triunfo definitivo do sistema representativo, não só para a França mas para a Europa inteira». Por outro lado, o 59.o ponto desse mesmo concurso, numa significativa ligação do absolutismo iluminado pombalino ao liberalismo - interpretação característica do tempo, nomeadamente nos meios republicanos - tinha o seguinte texto: «Portugal levanta-se da decadência em que se achava, desde a queda do Marquês de Pom-

(49) Vide, supra, nts. 9 e 11.

(50) Manual de Historia Universal, p. 348. 
bal, pela admissão das ideias liberais» $\left({ }^{51}\right)$. Mais tarde, no concurso de 1903-1904, três questões apontavam para o tratamento das revoluções segundo um modelo científico de causalidade: "A Revolução francesa: suas causas e consequências», "A Revolução de 1830: suas causas e consequências» e «A revolução de 1848: suas causas e consequências» $\left({ }^{52}\right)$.

Apesar disso, a importância conferida à Antiguidade e à Idade Média era ainda muito grande. De tal forma que dos 60 pontos do referido concurso de 1878 , tendo em conta que um se reportava a matéria de natureza geral, 33 eram dedicados à Antiguidade Oriental e Greco-Romana (55\%) e 14 à época medieval $(23,3 \%)$, ao passo que à época moderna só lhe eram referidos 9 (15\%) e ao período posterior à Revolução Francesa $3(5 \%)\left({ }^{53}\right)$. No concurso de 1903-1904 o desnível é ainda acentuado, se bem que se verifique um aumento sensível dos temas concernentes à «época contemporânea». Com efeito, metade dos 60 temas, precisamente 30 e num bloco à parte, eram concedidos à Antiguidade $(50 \%)$, a Idade Média é questionada em 15 temas (25\%), a época moderna em 9 (15\%) e os tempos mais próximos em $6(10 \%)\left({ }^{54}\right)$.

Também no manual de Consiglieri Pedroso se continua a notar o desnível referido, ainda que significativamente menos sensível do que no de Sousa Dória. Com efeito, se os estudos de Antiguidade têm um pendor muito importante - 190 páginas são-lhe dedicadas num volume de $352(53,9 \%)$ - a Idade Média (62 páginas: $17,6 \%$ ) conhece um tratamento menos desenvolvido do que a Idade Moderna (68 páginas: 19,3\%), continuando todavia a Idade Contemporânea (agora já assim explicitada) a ter um tratamento menor (32 páginas: 9,1\%).

A importância que era ainda conferida pelos próprios positivistas à Antiguidade - resultado da sua educação de raiz, da importância que então adquiriam as investigações orientalistas, em que se salientou Guilherme de Vasconcelos Abreu, professor de literatura e línguas védica e sânscrita no Curso Superior de Letras, e da própria análise filosófica da história que se iniciava no estudo do "estado teológico» - parece poder ser comprovada pelo interesse que lhe manifestaram nos seus estudos e nas suas reflexões. Teófilo Braga num ensaio de História Universal começa pelas civilizações orientais, de que

(51) Vide Busquets de Aguilar, O Curso Superior de Letras, p. 191.

(52) Idem, p. 273.

(53) Idem, pp. 185-191.

(54) Idem, pp. 268-273. 


\section{Revista de História das Ideias}

não chega a sair $\left({ }^{55}\right)$, Consigleri Pedroso, estudando As grandes épocas da História Universal, num conjunto de conferências, não ultrapassou também a análise da Antiguidade Oriental $\left({ }^{56}\right)$, e Teixeira Bastos, na crítica que moveu ao manual de Consiglieri, quase resume as suas considerações sobre «erros» que diz ter detectado a questões do mundo antigo $\left({ }^{57}\right)$.

7. Durante a República, como dissemos, verifica-se, sobretudo, a afirmação de duas grandes linhas de orientação relativamente ao ensino da História.

Uma delas assentava directamente nas concepções positivistas e pretendia integrar o referido ensino no campo mais vasto da Sociologia. Era afinal a renovação das ideias comtianas, que encontraram em Teófilo Braga um difusor consagrado, no seu plano de instituir uma Faculdade de Sociologia. Adolfo Lima aparece como o representante desta corrente relativamente ao problema concreto do ensino da História $\left({ }^{58}\right)$, acabando por influir na elaboração dos programas das Escolas Normais $\left({ }^{59}\right)$. A institucionalização do ensino da «História Geral da Civilização», ministrada nos liceus já no final da Monarquia, é revelador também desse sentido «social» que se procurava imprimir à pedagogia $\left({ }^{60}\right)$.

Noutra área, colocava-se um vasto e diversificado leque de intelectuais e pedagogos em que pontificava Fidelino de Figueiredo e o seu importante movimento para a reforma dos estudos históricos. Foi ele o autor de uma proposta de reforma que veio a ter a sua sequência em termos de legislação escolar $\left({ }^{61}\right)$. Como atrás se disse, a posição de Fidelino, embora se enquadrasse numa visão «social» da História, repelia as concepções positivistas e sobretudo os seus excessos «cientistas»

(55) Cfr. Historia Universal. Esboço de sociologia descriptiva: prolegomenos. Parte I. Civilisações fundadas sobre o empyrismo do estado e das artes industriaes: Egypto, Chaldêa, Babylonia e Assyria. Lisboa, Nova Livraria Internacional, 1878.

(56) As grandes epocas da Historia Universal, Porto, Imprensa Civilização, 1883.

(57) Cfr. artigo cit., supra, nt. 9.

(58) Cfr. $O$ ensino da "História". Comunicação feita perante a Sociedade de Estudos Pedagogicos de Lisboa na sessão de 8 de Abril

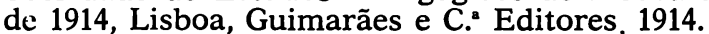
1916.

(59) Cfr. Diário do Governo, n. 24, 1." série. 10 de Fevereiro de

(60) Cfr. Programmas para a instrução secundaria aprovados por Decreto de 3 de novembro de 1905. Coimbra, Imprensa da Universidade, 1914, pp. 29-31.

(81) Cfr. "Programas de História no ensino secundário», Revista de História, vol. IV, Lisboa, 1915, pp. 38 ss. Vide também decreto n. 5002 , in Diário do Governo, n.o 257, 1.a série, 28 de Novembro de 1918. 


\section{A Revolução Francesa no Ensino da História}

e «naturalistas» e as suas explicações exageradamente «causalistas». Homem de sensibilidade literária e «filosófica», procurava antes encontrar a «alma» da História. Daí que a sua grande aposta vai particularmente no sentido da «nacionalização» do seu ensino. A História de Portugal atingia então uma importância fundamental no quadro dos programas propostos, prolongando-se a sua aprendizagem por 3 ou 5 anos (no caso dos estudantes que optassem pelo «curso complementar de Letras»). Além disso, se nos primeiros anos se lhe procurava conferir um sentido «essencialmente moral e patriótico», nos últimos desdobrava-se em estudos práticos de «história local», de modo a desenvolver nos alunos o «espírito municipalista», que fazia parte da tradição administrativa e social portuguesa.

Nestes moldes, parece evidente que o ensino de fenómenos que não se radicavam na realidade portuguesa assumiria um papel subalterno. De resto, segundo o programa de Fidelino de Figueiredo, a História Universal era leccionada em 2 anos, destinando-se um deles a ensinar todo o lapso de tempo que vai da Idade Média à época contemporânea (ou seja aos finais do século XIX), ao passo que num outro ano. (curiosamente o segundo) se ministrariam os conhecimentos relativos à Antiguidade, que continuava, pois, a ter um peso significativo no ensino. Assim, a Revolução Francesa não tinha no contexto programático qualquer sentido particular, se bem que se revele o cuidado de, na História de Portugal, se acentuar, na galeria de heróis, o significado dos «revolucionários» e liberais. Deste modo, entre os homens do liberalismo são referidos expressamente os nomes de Freire de Andrade, Fernandes Tomás, José Estêvão, Sá da Bandeira e Mousinho da Silveira.

Não nos parece, todavia, que mesmo os fenómenos liberais portugueses tivessem grande impacto na nossa memória histórica. Com as constantes crises da República, com as tentativas «ordeiras» ou ditatoriais que se processam depois de 1915 e até com os golpes de estado tendentes à restauração da Monarquia, com os conflitos entre o Estado e a Igreja e com o ressuscitar das ideologias católicas, com a entrada de Portugal na $1 .^{\mathrm{a}}$ Guerra e com as intenções para desenvolver uma consciência nacionalista, com o ambiente de instabilidade que se vivia e com os ecos que chegavam da revolução bolchevista, não havia tanto um ambiente favorável à celebração das revoluções liberais como das tradições históricas portuguesas ligadas ao sentido da pátria, à cultura nacional, à nossa propalada sensibilidade poética e até à nossa catolicidade. As invasões francesas tinham sido objecto de estudos diversos e de celebrações significativas coincidentes com o centenário da «Guerra 
Peninsular» $\left({ }^{62}\right)$, mas a Revolução de 1820 , apesar de ter sido celebrada, sobretudo nos locais que a ela estiveram mais directcimente ligados, Porto, Lisboa e Figueira da Foz (terra natal de Fernandes Tomás), não foi - segundo julgamos - tema de um grande centenário nacional que dinamizasse a ideia republicana $\left({ }^{63}\right)$.

Daqui não se conclua, todavia, que o movimento republicano não tivesse procurado divulgar os acontecimentos e as figuras que estavam de acordo com o seu processo político. Assim aconteceu, efectivamente. Recorde-se, por exemplo, a edição monumental da História do Regimen Republicano em Portugal, dirigida por Luís de Montalvor e que só veio a ser publicada em 1930-32, não passando, na verdade, de uma fundamentação da República com base nas realizações históricas que antecederam de perto e de longe o movimento vitorioso de 1910. Lembre-se também os curiosos cadernos de divulgação da Enciclopédia pela Imagem, que continham alguns números significatives, como as Lutas liberais, de Carlos Babo, e $A$ Revolução Francesa, ambos publicados à roda de $1925\left({ }^{64}\right)$. Saliente-se o significado da criação de uma «Biblioteca Democrática» na Imprensa da Universidade de Coimbra, então dirigida por Joaquim de Carvalho, que conteria as obras dos mestres do pensamento republicano, iniciando-se a colecção com Henriques Nogueira. Assinale-se, evidentemente, a publicação da revista Seara Nova em 1921, tendo em vista revivificar e renovar a ideia republicana, ainda que com certas ambiguidades. $\mathrm{E}$ registe-se mesmo o esforço de certos sectores republicanos e maçónicos, a partir sobretuda de 1925, para de novo dar alma às Comemorações Pombalinas, espécie de símbolo do avanço do

(62) Apenas como amostragem veja-se, neste volume, no Catálogo da Exposição Bibliográfica, realizada no decorrer do colóquio "A Revolução Francesa e a Península Ibérica», a quantidade significativa de obras sobre o tema.

(63) Sobre as celebrações de 1920, veja-se, por exemplo, o artigo "A Revolução de 1820. Lisboa, Porto e Figueira da Foz vão comemorar com imponência o centenário desta grande data», in $A$ Voz da Justiça, Figueira da Foz, ano 19., n. 1810,27 de Julho de 1920. Apesar desta intenção comemorativa-que aliás teve também episódios significativos em 1911-não nos parece, todavia, que se tivesse verificado um grande centenário nacional de impacto popular, como sucedeu com os centenários de Camões e de Pombal e se verificará em $1940 \mathrm{com}$ os Centenários da Fundação de Portugal e da Restauração. Mesmo do ponto de vista de produção de textos historiográficos, parece-nos ter sido muito pobre.

(64) Carlos Babo, As luctas liberaes, Porto, Livraria Chardron, s.d.; A. Alba. A Revolução Francesa, trad. de Guedes de Oliveira, Porto, Lello e Irmão, s.d. 


\section{A Revolução Francesa no Ensino da História}

seu movimento, através de uma edição filatélica com o objectivo de levar finalmente a cabo a construção da estátua da Rotunda.

No entanto, o certo é que a acção levada a efeito no sentido da nacionalização da história portuguesa, em que cooperaram intelectuais monárquicos e republicanos, como Fidelino de Figueiredo e Jaime Cortesão, não favoreciam o reavivar de fenómenos ligados à consciência liberal e democrática. Não será, assim, por acaso, que na Revista de História, dirigida por Fidelino de Figueiredo, tirando uns excertos de um historiador anónima de Pombal, a transcrição de alguns passos do diário de um liberal e do diário de um soldado miguelista, a publicação de alguns documentos referentes à época liberal ou algumas recensões a obras sobre o liberalismo, mais nenhum artigo se refira a temas da história contemporânea portuguesa ou a temas referentes às preocupações político-culturais e histórico-políticas consagradas pelo movimento republicano. Mesmo os temas literários não se reportavam, essencialmente, ao período liberal, não existindo nenhum grande romance ou peça de teatro que possa incluir-se no que se entende como uma literatura engagée, ligada a um ideário democrático. No século passado aparecem alguns textos ligados com as Invasões Francesas que, como temos dito, preenchem, elas sim, o nosso imaginário histórico e patriótico - é o caso, por exemplo, de O Sargento-Mor de Vilar (1863), de Arnaldo Gama, ou A Casa dos fantasmas (1865), de Rebelo da Silva - tema que será por isso retomado no século presente em textos literários ou de pretensão histórico-literária (é o caso do romance histórico de Fonseca Benevides, No tempo dos franceses, 1908, ou de El-Rei Junot de Raúl Brandão, 1912). $\mathrm{Na}$ nossa centúria é também abundante a literatura e as memórias sobre a $1 .^{\text {a }}$ Grande Guerra, que tem, como o tema anterior, uma larga popularidade ao nível da arquitectura comemorativa. Já o mesmo, porém, não se poderá dizer do fenómeno liberal em si. O que se verifica, em profusão, é (como atrás se disse) o retomar dos velhos temas da tradição histórico-literária portuguesa. No domínio do teatro, isso torna-se então de uma notória vulgaridade. Recorde-se apenas, para citar alguns exemplos, as peças de Antero de Figueiredo ( $D$. Pedro e D. Inês, 1913; Leonor Teles, 1916; D. Sebastião, 1925), de António Patrício (Pedro o Cru, 1918; Dinis e Isabel, 1919) e até de Jaime Cortesão (Infante Santo, 1916; Egas Moniz, 1918). Por sua vez, a corrente poética de feição nacionalista (em certos casos em ligação com o Integralismo) radicava também muitos dos seus temas na «história antiga» de Portugal — é isso que sucede com Teixeira de Pascoaes, Afonso Lopes Vieira ou António Correia de Oliveira. Isto ao mesmo tempo que se 
verificava o «revivalismo» na arte e o sonho da «casa portuguesa» de Raúl Lino.

8. O Salazarismo, sobretudo na sua projecção dos anos 30-40, vai encaminhar, intensificar e enquadrar este movimento nacionalista nascente, que ia assumindo uma forma totalitária nos regimes italiano e alemão. De resto, Salazar faz iniciar o seu "consulado» de cerca de 40 anos com uma grande celebração histórica, que procurava, pela via nacionalista, reforçar a sua imagem ideológica e a sua força política. Trata-se do Centenário da Fundação da Nacionalidade e da Restauração, que se verifica em 1940, mas que foi preparado com vários anos de antecedência.

Evidentemente que, neste contexto, fenómenos como a Revolução Francesa eram em geral entendidos como espúrios e semeadores de discórdia, como factores degradativos da alma nacional. E assim que a interpreta António de Sèves, numa conferência da Sociedade de Geografia, que intitulou $A$ Revoção Francesa e suas consequências, onde se interligam os seus «perigos» com os "perigos» do Presente e se faz profissão de fé do espírito contra-revolucionário, salvador da «civilização ocidental» ${ }^{(65)}$. De forma idêntica, o liberalismo português era interpretado como a «história negra» do país, à qual se seguia outra «história negra», que constituía a República, no final da qual se abria, finalmente, a alvorada salazarista. A História de Portugal de João Ameal, publicada em 1940, que recebeu no ano seguinte o Prémio de História "Alexandre Herculano» do Secretariado de Propaganda Nacional (S.P.N.), é a obra mais reveladora da ideologia histórica do regime. «Sob o signo de Caim» é o título que Ameal confere ao período da história de Portugal marcado pelo liberalismo. Ressuscitando a velha ideologia de Barruel, divulgada em Portugal sobretudo por Agostinho de Macedo, apresenta a Revolução de 1820 como a afirmação do espírito estrangeiro e antipatriótico, maçónico, irreligioso e fratricida, de que as ideias liberais eram portadoras. «E o. Diabo à solta (conclui) - o diabo do individualismo anárquico, da mentirosa e desastrosa soberania do povo, da 'Revolução satânica'! ${ }^{\left({ }^{86}\right)}$. E idênticas diatribes aparecem numa

(65) António de Sèves, A revolução Francesa le suas consequências. Conferência lida na Sala Algarve da Sociedade de Geografia, na noite de 23 de Maio de 1944, sob a presidência de S. Excelência o Conselheiro João de Azevedo Coutinho, Lisboa, Pro Domo. 1944.

(68) Cfr. João Ameal, História de Portugal, Porto, Livraria Tavares Martins, 1940 (sucederam-se a esta várias edições), pp. 605 ss. Cfr. o passo transcrito na p. 616. 
História breve de Portugal, de Caetano Beirão, que foi depois traduzida em inglês e francês para divulgação oficial $\left({ }^{67}\right)$.

E certo que este discurso ideológico não passou assim, literalmente, para os manuais escolares. No entanto, o seu espírito lá se encontra. Procurando cuidadosamente organizar os programas de História e os seus manuais - Salazar entendeu que era em grande parte através do ensino da História, lato sensu, que poderia ganhar a batalha da ideologia - o «Estado Novo» procura, como dissemos, intensificar o espírito nacionalista e reprimir o que entendia como estrangeirismo liberal-revolucionário. Consultando os compêndios dos anos 30-40, isso é evidente, quer explicitamente, quer nas entrelinhas.

Por exemplo, no Compêndio de História Universal de António Mattoso fazia-se uma leitura de «direita» da Revolução e das suas personagens. Luís XVI só tem como defeitos a falta de autoridade e o sentido de concórdia que sempre o caracterizou, ao passo que todos os revolucionários, desde Lafayette a Robespierre, se caracterizam pela desumanidade. O processo revolucionário é entendido como um movimento de destruição, comandado pelos clubes políticos e pela maçonaria. Não era possível, perante a leitura deste manual - que curiosamente, na primeira versão, coloca lado a lado os Chefes dos regimes nacionalistas e os seus movimentos de jovens, Hitler e a juventude nazi, Mussolini e a juventude fascista e Salazar e a Mocidade Portuguesa - e até das suas imagens legendadas, ficar com uma ideia positiva, por mínima que fosse, da "Grande Revolução» ( $\left.{ }^{68}\right)$. A matriz era sobretudo La Révolution Française, obra da juventude de Pierre Gaxotte, que de resto haveria de ser traduzida para português, tendo tido mais de uma edição ${ }^{\left({ }^{69}\right)}$.

(87) Caetano Beirão, História breve de Portugal, Lisboa, Edições Logos, s.d., sobretudo pp. 111 ss.

(68) Cfr. António G. Mattoso, Compêndio de História Universal aprovado como livro único para o 4. e 5. anos dos Liceus, Lisboa, Livraria Sá da Costa, s.d., pp. 382 ss.

(69) P. Gaxotte. La Revolution Française, Paris, 1928. A obra foi traduzida para português: A Revolução Francesa, trad. do prof. Eduardo Pinheiro, Porto, 1945 (2: edição, Porto, Livraria Tavares Martins. 1962). Diga-se, de resto, que Gaxotte esteve ligado a concepções corporativas e fora admirador do Salazarismo, tendo prefaciado a edição francesa da síntese do seu pensamento (Oliveira Salazar. Principes d'action, précédés de «Reflexions en marge de la Révolution National Portugaise» par Pierre Gaxotte, Paris, Fayard, 1956). 
Por outro lado, na História de Portugal do mesmo António Mattoso é evidente uma opinião idêntica relativamente à Revolução de 1820 , aos seus fautores e aos acontecimentos e personagens que os antecedem. A par da simpatia com que são encarados D. João VI e Carlota Joaquina, verifica-se facilmente o modo pouco reverente com que são tratados os revolucionários e pré-revolucionários. Todo o processo vintista é, assim, entendido como um movimento maçónico e antinacional, dirigido de fora e em consonância com ideias e interesses estrangeiros $\left({ }^{70}\right)$. Apenas um texto de síntese do compendiarista: «Apesar disto os liberais agitam-se para dar mais 'felicidade' a este povo, que consideram infeliz. A 'felicidade do povo' serve, é claro, para justificar as ambições dum grupo. E para as levarem a efeito lançam mão de todos os meios. Não duvidam sequer em sacrificar a nacionalidade...» $\left({ }^{71}\right)$.

Se confrontarmos agora o manual de Alfredo Pimenta $\left({ }^{72}\right)$, aí encontramos o retrato de Gomes Freire como de um «desnacionalizado" - ideia esta que era, de resto, partilhada por toda a ideologia "contra-revolucionária» $\left({ }^{73}\right)$ - e a imagem da Revolução de 1820 como "a anarquia das casernas e das ruas». Esta e muitas outras observações eram entremeadas por sugestivas gravuras onde se nota a ausência dos vintistas e se destacam, sobretudo, para além de D. João VI («um dos reis mais caluniados da nossa história»), de Carlota Joaquina («figura curiosa de rainha que as paixões políticas deformaram») e de D. Miguel («rei legítimo de Portugal»), a dos contra-revolucionários Frei Fortunato de São Boaventura e José Agostinho de Macedo. Mas se a História de Pimenta - «um livro de história cristã e portuguesa», no dizer do Cardeal Cerejeira $\left({ }^{74}\right)$ - acabou a breve trecho por deixar de ser considerada como manual escolar, os compêndios de Mattoso foram considerados como «livros únicos» durante dezenas de anos.

Algo de idêntico se passa com a História de Portugal de Tomaz de Barros, que serviu a gerações sucessivas de estudantes da escola primária, onde os clichés são exactamente os mesmos. A anarquia constituía a nota mais evidente que resultara da

(70) Compêndio de História de Portugal, Lisboa, Livraria Sá da Costa, 1938, pp. 651 ss.

(71) Ob. cit., p. 656.

(72) Elementos de História de Portugal. Lisboa, Empresa Nacional de Publicidade, 1934, pp. 486 ss.

(73) Ver, por exemplo, A. Neves da Costa, A traição de Gomes Freire, Lisboa, Sociedade Astória, 1935.

(74) Cfr. Alfredo Pimenta, Os meos "Elementos de História de Portugal» e a crítica, Ed. do Autor, Lisboa, 1936. 


\section{A Revolução Francesa no Ensino da História}

revolução liberal $\left({ }^{75}\right)$. Era, pois, essa «imagem negra» que, desde crianças, os alunos colhiam nos bancos das escolas. Mesmo quando os novos programas do ensino primário são introduzidos no início da década de 70 e, assim, a cronológica história de Portugal é substituída por um ensino mais ligeiro, onde uma galeria de «figuras exemplares da história nacional» é entremeada com o registo de aspectos da vida social - os transportes, a habitação, o vestuário, etc. - não encontramos entre essas figuras nenhum revolucionário. São os exploradores africanos os grandes exemplos da história do século XIX, o que de resto se coadunava com a situação de crise colonial por que o país passava $\left({ }^{78}\right)$.

Diga-se, no entanto, que, sobretudo ao nível do ensino secundário, foi-se escoando o sentido nacionalista do ensino da História e a sua imagem contra-revolucionária. Com a reforma de 1948, a integração, numa visão universalista, do estudo da história de Portugal e da história europeia na história geral, bem como a dimensão «social» que se procurara de novo imprimir à História - é curioso o regresso da «História Geral da Civilização», bem assim como uma teorização que nos pareceu, em certos casos, de sabor neo-positivista - parecem reveladoras de uma certa inversão $\left({ }^{77}\right)$. Neste contexto, os manuais de António Mattoso vão sofrendo algumas transformações significativas $\left({ }^{78}\right)$ e o aparecimento de outros compêndios pelos anos 60 marcam o processo de diluição da vulgata do ensino da História.

9. Outro aspecto que deve ser salientado no espírito do programa de 1948 é o facto de apontar, como objectivo pri-

(75) Cfr. Sumário de História de Portugal, Lisboa, Editora Educação Nacional, 1945 (18." ed.), pp. 146 ss. A ideia de que a revolução liberal representa a anarquia é sintetizada de forma exemplar num outro manual dos anos 60, o Epitome de História de Portugal, de Marques de Queirós, Porto, Papelaria dos Carvalhos, s.d. Fazendo um quadro-síntese de cada período da história, é assim que caracteriza o que chama o "2.o período» da 4." dinastia (desde D. João VI à República): "O regime liberal instala-se em Portugal, e, com os seus defeitos, conduz o país a situações muito graves» (na 8." ed., p. 84).

(76) Cfr. por ex., Pedro de Carvalho, História de Portugal para a 4. classe, Porto, Porto Editora, s.d., pp. 82-83.

(77) Cfr. Programas das disciplinas do Ensino Liceal. Decreto n. 37.112, de 22 de Outubro de 1948, Lisboa, Imprensa Nacional, 1948, sobretudo pp. 99 ss. (Vide supra).

(78) Compare-se o manual citado de História Universal com a edição Compêndio de História Universal. 5. ano, Lisboa, Sá da Costa, 1965. Neste último, para além de um maior cuidado científico, é evidente, por parte do autor, o desejo de eliminar as observações mais polémicas. 
mordial do ensino da História, o conhecimento da «génese» e das «características do mundo contemporâneo», sem que essa finalidade se ligasse de uma forma particular - como até aí acontecera - aos valores «nacionalistas-cristãos». Relevavam-se antes as realidades sociais características da revolução industrial, ainda que, como é óbvio, não deixasse de se valorizar o papel social da Igreja Católica $\left({ }^{79}\right)$.

Pode dizer-se, de resto, que a pouco e pouco os estudos contemporâneos, entendidos em novas perspectivas - no âmbito da «história política», "positivista» e «documentalista», geralmente centrada nas figuras dos reis ou das grandes personagens e por vezes com acentuadas preocupações ideológicas, na

(79) Nas "Observações» aos programas de História da reforma de 48 pode ler-se logo no início: «O ensino da História nos liceus deve assentar, de um modo geral, no estudo das transmutações sofridas pela sociedade e pelo homem, que dêem a conhecer ao aluno a génese e as características do mundo contemporâneo e os valores que dominam o seu espírito e a sua estrutura" (Programas das disciplinas do Ensino Liceal. Decreto n. 37.112 , de 22 de Outubro de 1948, ed. cit., p. 116). É curioso que, em certa medida, retomava-se o texto das "Observações» dos programas de 1936, despindo-o, todavia, da inflexão "nacionalista-cristã". "A disciplina de história, além do fim inerente a todo o ensino liceal, tem como função especial dar a conhecer as transformações sofridas pela sociedade e pelo homem, com o intuito de provocar uma compreensão dos aspectos da sociedade contemporânea e dos valores que dominam a sua estrutura, com particular referência à missão histórica da Nacão Portuguesa, dentro do ideal cristão" (Decreto n. 27.085. de 14 de Outubro de 1936). As "Observações» do programa de 48 referentes ao ensino da história contemporânea diziam: "Na História da Idade Contemporânea, faça-se sobressair o novo aspecto económico, político e social do Mundo, ligado ao industrialismo, aos efeitos dos grandes eventos, ao predomínio da burguesia e à importância crescente do operariado, assim como as acentuadas rivalidades entre as orandes potências e também a accão da Igreia Católica perante a questão social e o neo-pragmatismo" (Programa cit., p. 119). Deve ainda esclarecer-se que o interesse directo vela história contemporânea sofreu uma nítida quebra com a estabilizacão e dinamizacão ideológica do regime salazarista. $\mathrm{Na}$ verdade, ainda nos programas de 1934 o seu estudo, relativamente à história universal e à história de Portugal, ocupava todo um ano, a 5. ${ }^{\mathrm{a}}$ classe dos liceus, o que de resto representaria a sobrevivência das preocupações republicanas. Só em 1936 se verifica a referida quebra, passando a ensinar-se na 5." classe a história moderna e a história contemporânea para em 1948 se verificar um relativo alargamento do espaço desta última, destinando-se o programa do agora $5 .^{\circ}$ ano liceal ao ensino de parte da época moderna (depois do século XVII) e da época contemporânea, enquanto nos dois anos anteriores - o ensino da História segundo os programas de 36 confinava-se, no curso geral dos liceus, às 4." e $5 .^{\mathrm{a}}$ classes - se ensinava no 3.9 ano a Antiguidade e no $4 .^{\circ}$ a Idade Média e parte da Idade Moderna (até ao século XVI). 
verdade nunca morreram $\left({ }^{80}\right)$ - iam reentrando no espaço historiográfico português, se bem que de forma lenta e, em regra, fora do contexto universitário ou, mesmo que no âmbito da Universidade, um pouco numa situação marginal. Assim, desde os finais dos anos 50 e sobretudo na década de 60 (o caso da publicação da obra de Julião Soares Azevedo é praticamente uma excepção) ( ${ }^{81}$ ) surgem editados os primeiros estudos de preocupações «sociais» sobre o século XIX, normalmente da autoria de historiadores de esquerda. São os casos dos estudos de Vitorino Magalhães Godinho, Joel Serrão, Victor de Sá, Piteira Santos, José Tengarrinha, Armando de Castro, Augusto da Costa Dias ou Miriam Halpern Pereira $\left({ }^{82}\right)$. Por sua vez, algumas re-

(80) Recorde-se que a História de Portugal dirigida por Damião Peres, cuja publicação se integrou no centenário da Fundação da Nacionalıade, que ocorreria em 1940, dedicou um volume à época contemporânea (vol. VII, Barcelos, Portucalense Editora, 1935). Apesar do seu interesse, nomeadamente de alguns dos seus capítulos, náo deixa também de ser verdade que é ainda elaborado numa perspectiva «narrativa", tendo como denominador básico o factor "político». Pode também lembrar-se que, pelos anos 30-50, na continuação de outras obras eruditas aparecidas nos decénios anteriores, foram publicados vários estudos relativamente ao período liberal e para-liberal, mas, como acima dissemos, centrados ainda nas figuras dos reis e das grandes personagens. Citemos, apenas como exemplo, os seguintes: Carlos Passos, D. Pedro IV e D. Miguel I, Porto, 1936 (entre outras obras sobre a polémica da sucessão, algumas de nítido sentido «legitimista»); Ângelo Pereira, D. João VI, Príncipe e Rei, 4 vols., Lisboa, 1953-1958; Damião Peres, D. Pedro V nas páginas do seu diário intimo. Porto, 1945; Ruben Andresen Leitão, D. Pedro V. Um homem e um rei, Porto, 1950; F.M. da Costa Lobo, $O$ Conselheiro José Luciano de Castro e o segundo periodo constitucional monárquico, Coimbra, 1941; Henrique de Barros, Mousinho da Silveira e a sua obra, Lisboa, 1936; António Ferreira, O Cardeal Saraiva. Porto, 1948. Pode ainda acrescentar-se que se publicaram também alguns documentos, entre os quais poderemos destacar algumas memórias: Memórias de Francisco Manuel Trigoso de Aragão Morato, Coimbra, Imprensa da Universidade, 1933, e Memórias do Conde de Lavradio D. Francisco de Almeida Portugal, 8 vols., Coimbra-Lisboa, Imprensa da Universidade-Imprensa Nacional, 1932-1943.

(81) Condições económicas da Revolução Portuguesa de 1820, Lisboa. Empresa Contemporânea de Edições, 1944.

(82) V. Magalhães Godinho, Prix et monnaies au Portugal: 1750-1850, Paris, 1956; Joel Serrão, Temas oitocentistas. Para a história de Portugal no século passado, Lisboa, Atica, 1959; Victor de Sá, A Revolução de 1836, Lisboa, 1969, e A crise do liberalismo e as primeiras manifestações das ideias socialistas em Portugal (1820-1852), Lisboa, 1969; Piteira Santos, Geografia e economia da Revolução de 1820, Lisboa, Europa-América, 1962; J. Tengarrinha, História da imprensa periódica portuguesa, Lisboa, Portugália, 1965; A. de Castro, A Revolução Industrial em Portugal no século XIX. Lisboa, D. Quixote, 1971 (2.a ed.); A. da Costa Dias, $A$ crise da consciência pequeno-burguesa. I-O nacionalismo literário da geração de 90, Lisboa, Portugália, 1962, e Discursos 


\section{Revista de História das Ideias}

vistas culturais «de oposição» publicam interpretações históricas sobre o século $\mathrm{XIX}$ português ou sobre o movimento revolucionario francês $\left({ }^{83}\right)$; historiadores estrangeiros - com destaque particular para Albert Silbert - começam a ocupar-se com o estudo da nossa realidade oitocentista $\left({ }^{84}\right)$; e, mesmo no domínio da literatura de preocupações políticas democráticas, não pode deixar de se recordar a sedução exercida pelo nosso movimento para-liberal de 1817 e por Gomes Freire, como sucedeu com a peça de Luís de Sttau Monteiro, Felizmente há luar, e já acontecera decénios atrás, em termos de literatura histórica, com Raúl Brandão e António Ferrão, e em termos de romance, com Rocha Martins ( $\left.{ }^{85}\right)$. Entretanto, a Revolução Francesa era objecto de algumas traduções significativas. $\mathrm{Na}$ verdade, se a versão portuguesa de Gaxotte se integra na visão contra-revolucionária da Revolução, se a tradução da obra de Arthur Booth, The true book about the French Revolution, publicada pela Livraria Civilização do Porto em $1961\left({ }^{86}\right)$, tem apenas o sentido da divulgação histórico-literária, se a tradução da síntese da colecção "Que-sais-je?» na paralela colecção «Saber», da autoria de Paul Nicolle, se explica no contexto da divulgação cientí-

sobre a liberdade de imprensa no primeiro parlamento português (1821), Lisboa, Portugália, 1966, M. Halpern Pereira, Livre-câmbio e desenvolvimento económico: Portugal na segunda metade do século XIX, Lisboa, Edições Cosmos, 1971.

(83) $\mathrm{E}$ isso q $\mathrm{e}$ acontece, por exemplo, com a Vértice, de Coimbra. Já em 1948 Borges de Macedo ali publicara um artigo sobre «A Revolução de 1848 em Portugal». E, porém, nos anos 60 e 70 que surgem artigos sobre os temas referidos em maior quantidade. Em 1964 Flausino Torres escrevia «A propósito de.... Revolução Francesa» (pp. 160 ss.), em 1969 Victor de Sá publicava «Características do Liberalismo em Portugal» (pp. 82 ss.), em 1973 Avelãs Nunes apresentava o artigo "Significado da Revolução Francesa na história do Capitalismo» (pp. 234-260, 362-377 e 564-579).

(84) Albert Silbert, Do Portugal do Antigo Regime ao Portugal oitocentista, Lisboa, Horizonte, 1972. Em 1964, Silbert apresentara na Sorbonne a tese Le Portugal Mediterranéen à la fin de l'Ancien Régime, hà alguns anos publicado em 2." edição, Lisboa, I.N.I.C., 1978 (3 volumes), tendo publicado ainda Le problème agraire portugais au temps des premières Cortès libérales (1821-1823), Paris, P.U.F. - Centre Culturel Portugais, Fondation C. Gulbenkian. 1968.

(85) L. de Sttau Monteiro, Felizmente há luar, Lisboa, 1961; Raúl Brandão, A conspiração de 1817 - Gomes Freire, Porto, Companhia Portuguesa Editora, 1914; António Ferrão, Gomes Freire na Rússia, Coimbra 1917, e Gomes Freire $e$ as virtudes da raça portuguesa, Coimbra, 1920 Rncha Martins escreveu um romance histórico de defesa de Gomes Freire contra as acusações de anti-liberais, que publicou em folhetim.

(86) Arthır H. Booth, A Revolução Francesa, Porto, Livraria Civilização, Col. "Quer saber....», 1961. 
fica $\left.{ }^{87}\right)$, já a edição em português da obra de Albert Mathiez representa, acima de tudo, a intenção de apresentar uma grande revisão historiográfica sobre a interpretação da Revolução Francesa. Sintomaticamente a edição desta obra, aparecida em 1957, é publicada por uma cooperativa do Porto e prefaciada por um intelectual de esquerda, Óscar Lopes ${ }^{(88)}$. Entretanto, outras traduções aparecem e algumas delas representam interpretações marxistas da Revolução. É o caso da obra de A. Manfred, publicada pela primeira vez em $1963\left({ }^{89}\right)$. Obras deste tipo eram apreendidas pela censura salazarista e marcelista $\left({ }^{90}\right)$.

Eram naturalmente também objecto de censura pequenos textos divulgativos de tipo histórico-ideológico que se integravam na prática comunista. o que sucede com um pequeno folheto intitulado As causas profundas da Revolução Francesa, publicado à roda de $1948\left({ }^{91}\right)$, quando, em período de pós-guerra, a oposição rejuvenescia na esperança democrática. Mesmo a publicação póstuma da História das grandes revoluções, de Rocha Martins, pelo jornalista Jaime Carvalhão Duarte, insere-se perfeitamente nessa luta, que tinha as revoluções passadas como exemplo $\left({ }^{(92}\right)$.

(87) Paul Nicolle, A Revolução Francesa, Lisboa, Europa-América, 1962 (2." ed.).

(88) Albert Mathiez, História da Revolução Francesa, trad. de Alexandre Babo, introdução de Oscar Lopes. Porto, Imprensa Social, Secção da Cooperativa do Povo Portuense, 1957. A obra de Mathiez for editada em Paris, com o título La Révolution Française, em 1922-24 (3 vols.), sendo reeditada em 1960 (1 vol.).

(89) Albert Manfred, Revolução Francesa, Lisboa, Arcádia, Biblioteca Arcádia de Bolso (B.A.B.), 1963. A obra, que foi retirada da circulação pela Censura, reapareceu em 1972, altura em que se verificou uma relativa abertura. Em 1971 surgiu a tradução da obra de Albert Soboul, 1789 ano um da liberdade (Lisboa, Delfos, s.d.), aparecendo em 1974 a tradução da obra do mesmo autor Camponeses, sans-culottes e jacobinos, publicada pela Seara Nova.

(90) Cfr. Livros proibidos no regime fascista, Lisboa. Presidência do Conselho de Ministros, Comissão do Livro Negro sobre o Regime Fascista, 1981. Aí aparecem referenciados como sendo apreendidos pela Censura obras várias (traduções e edições originais) sobre a Revolução Francesa da autoria de Soboul, Manfred, Roger Vaillant, etc.

(91) Causas profundas da Revolução Francesa, Porto, "Renovaçâo Democrática", Cadernos do Povo, Petrus, s.d. Supomos que este "caderno" deve ter como data 1948, ou um ano próximo, pois foi então que deu entrada na Biblioteca Geral da Universidade de Coimbra onde o encontrámos. E de tipo claramente marxista, como, por exemplo, se pode verificar através desta "Conclusão»: "A Revolução Francesa é a ruptura violenta e necessária das relações de produção existentes sob o antigo regime feudal, para estabelecer novas relações de produção necessárias ao desenvolvimento do capitalismo".

(82) História das grandes revoluções (A génese do Mundo Novo), 2 vols., Lisboa, Organizações Crisalis, 1953. A Revolução Francesa é 
Por outro lado, no seio da Universidade também se vão operando algumas transformações. Da reforma de 1911, onde o ensino da História - no seguimento do modelo curricular do Curso Superior de Letras - se ligava ao ensino da Geografia, da Filosotia e até da Filologia e da Literatura $\left({ }^{93}\right)$, passa-se em 1930 para um ensino mais especificado, mas também mais ligado a concepções teóricas, na base do binómio História-Filosofia $\left({ }^{94}\right)$. Em 1957 dá-se, porém, um processo de especialização, com a criação propriamente do curso de História, mantendo-se esta reforma até 1974, apenas com algumas transformações pouco mais do que pontuais e de ordem curricular, em $1968\left({ }^{95}\right)$. Se em todos os currículos se verifica a existência de uma cadeira de História Moderna e Contemporânea - não deixa de ser curioso, a não ser que se trate de um simples lapso de legislação, que a reforma de 57 tenha introduzido uma disciplina de História da Cultura Moderna, e não de História da Cultura Moderna e Contemporânea, que levaria o aluno ao contacto "perigoso» com uma problemática cultural de actualidade, onde o marxismo se incluía - a verdade é que, de facto,

tratada no cap. $\mathrm{X}$ do vol. I. Através das palavras justificativas da edição, de Jaime Carvalhão Duarte, que elogia Rocha Martins como "soldado e pioneiro dos grandes ideais de justiça e de liberdade», e das palavras de apresentação da sua obra pelo autor verifica-se, realmente, embora de forma subreptícia, uma certa intenção ideológica nesta obra e na sua publicação. Rocha Martins, que escrevia no tempo da guerra, afirmava: "Sofro e analiso o actual cataclismo e ouço as mesmas palavras de Direito e de Justiça prometidas aos humildes como eu. Aguardo-as de coração ansioso, como os meus avós devem tor esperado os seus melhores dias prometidos, enquanto a tempestade guerreira se desencadeava. Entretanto, lembro as Grandes Revoluçōes e os seus resultados. crente que de tantos entrechoques e, em presença dc mais terrível de todos eles, alguma coisa de novo. realmente modificará a face social. A terra rola há milhares de anos e dir-se-ia que os sey's habitantes, como em colossal 'carroussel', voltam sempre ao ponto de partida. Desta vez dizem os estadistas responsáveis, como outros já o afirmaram noutras línguas, com outros trajes e em países diversos, que o mundo mudará. Conto o que sei das revoluções do Mundo Velho, esperando ser cidadão do Mundo Novo". Oscilando entre a defesa da monarquia liberal e a república, Rocha Martins acabou por cortar com o movimento republicano após o regicídio e, depois, por se lançar no trabalho de historiógrafo, que não o fez. todavia. perder a consciência política, participando com os seus artigos da Remública nas campanhas de oposicão ao regime salazarista.

(93) Dińrio do Governo. 19 de Agosto de 1911. pp. 1617 ss.

(94) Tei orgânica das Frcyldades de Letras. Decreto n. ${ }^{\circ} 18.003$, de 2.5 de Fevereiro de 1930. Coimbra. Universidade de Coimbra - Faculdade to T,etras. Coimhra F.ditora. 1930.

(95) Reforma das Faculdades de Letras. Decreto n. ${ }^{\circ} 41.341$, de 30 de Oitubro de 1957 Lishoa. Imprensa Nacional, 1957, e Decreto n. 48627 , de 12 de Outubro de 1968. 


\section{A Revolução Francesa no Ensino da História}

depois da ascensão do Salazarismo, não foram geralmente ensinadas matérias que ultrapassassem os séculos XVI-XVII ( ${ }^{\left({ }^{\mathbf{6}}\right)}$. $O$ sentido de uma leccionação «de especialidade» (por vezes do tipo de petite histoire), o «medo científico» da história dos tempos mais próximos e uma certa sensação de "perigo político» que o ensino dessas matérias supunha, pode explicar essa ausência. Para que tal fique comprovado diga-se claramente que em Coimbra, durante o Estado Novo e a gorada «Primavera Marcelista», o ensino da Revolução Francesa não foi ministrado na cadeira de História Moderna e Contemporânea senão nos anos 70, quase em vésperas do 25 de Abril $\left({ }^{97}\right)$, passando-se por certo algo de idêntico em Lisboa e no Porto. E ainda outro exemplo frisante no domínio da investigação científica universitária: na conceituada Revista Portuguesa de História, que se publica na Faculdade de Letras de Coimbra a partir de 1941, só nos anos 60-70 aparecem os primeiros artigos referentes a temas do século XIX $\left({ }^{98}\right)$. E, salvaguardando alguns casos, nota-se um vazio no que diz respeito à historiografia sobre essa época em outras revistas universitárias. Com excepções, como é o caso de Joaquim de Carvalho em Coimbra - que foi deixando ao longo da sua vida de investigador alguns trabalhos referentes ao período oitocentista e à problemática liberal e republicana - pode, pois, dizer-se que o panorama geral prima pelo silêncio em relação a essas realidades históricas $\left({ }^{99}\right)$.

(96) Consultando os livros de sumários escolares da Faculdade de Letras de Coimbra, verificou-se que o último programa da cadeira de História Moderna e Contemporânea que abordou a Revolução Francesa foi o de 1925-1926, leccionado por Gonçalves Cerejeira. Por outro lado, na disciplina de História de Portugal em nenhum tempo se abordou a temática contemporânea. De momento, não pudemos realizar idêntica pesquisa em Lisboa.

(97) Foi seu docente João Lourenço Roque, nessa altura jovem assistente, que significativamente utilizou já então alguma bibliografia que apresentava uma interpretação marxista da Revolução.

(88) Depois de dois artigos, de um brasileiro, Manuel Nunes Dias, e de um francês, A. Silbert, referentes ao século XIX, mas não a problemática liberal (vol. X, 1962, e vol. XI, 1964-68, respectivamente), surge o primeiro artigo também de um estrangeiro, o espanhol Antonio Eiras Roel, relativo ao liberalismo («Moderados y cartistas: la 'Pat»leia' y la reacción española», in vol. XI, 1964-68). Só em 1971 (vol. XIII) um português, Borges de Macedo, publica ali um artigo referente à temática liberal ( OO aparecimento em Portugal do conceito de programa político»), seguindo-se em 1977 outro de sua autoria, "Para o encontro de uma dinâmica concreta da sociedade portuguesa (1820-1863)».

(89) Para além da sua colaboração na História de Portugal de Damião Peres, recorde-se a sua participação na História do Regimen Republicano, a sua "Antheriana" e alguns estudos dispersos por revistas (por ex., "Manuel Fernandes Tomás: jurisconsulto», Revista de Guimarães, 1949). 


\section{Revista de História das Ideias}

Mas ainda assim, na área da pesquisa universitária, fcram penetrando, embora de forma parcimoniosa e hesitante, os estudos sobre a época contemporânea e, nomeadamente, sobre temas portugueses do liberalismo. Concretamente, será no seio dos seminários que orientavam as teses de licenciatura que serão abordadas essas questões - tratava-se aqui de um ensino ministrado em grupos mais pequenos, por vezes com o carácter quase «doméstico» e pessoal, cujos alunos faziam propostas de trabalho que os professores mais dificilmente poderiam recusar e em que docentes de concepções científicas e culturais mais avançadas se sentiam mais livres para propor pesquisas de âmbito epocal mais recente e de temário mais «arriscado». $\mathrm{Na}$ verdade, verificando os títulos e as datas das dissertações de licenciatura de Lisboa e de Coimbra, verifica-se que é pelos anos 50 e 60 que surgem sobretudo os estudos mais directa ou indirectamente ligados à problemática liberal. E não poderá deixar de se constatar que tal facto não está afastado da acção de certos docentes portadores de concepções culturais abertas a novas perspectivas de análise. Foi o que se passou em Lisboa, com Borges de Macedo ou Oliveira Marques (a sua transferência, a partir da emigração americana. da área de estudos medievalistas, de que é importante especialista, para a área de estudos contemporâneos não será por certo estranha à necessidade sentida de conhecer temas mais directamente relacicnados com a realidade democrática), em Coimbra com Silva Dias e no Porto com Oliveira Ramos, a quem se deve, segundo supomos, a primeira dissertacão de doutoramento em História sobre uma personalidade liberal, o Cardeal Saraiva, ainda que elaborada numa perspectiva académica $\left({ }^{100}\right)$.

Dissemos em História, porque na Universidade, nas áreas de Literatura, os autores liberais foram muito mais precocemente estudados em teses doutorais. Assim sucedeu com Herculano e Garrett $\left({ }^{101}\right)$. De resto, certo tipo de análises histórico-literárias, histórico-culturais e mesmo histórico-filosóficas sobre um passado recente conheceram, indubitavelmente, um desenvolvimento maior e uma aceitação mais normal, mesmo no campo universitário $\left({ }^{102}\right)$, não se verificando, pelo menos com

(100) O Cardeal Saraiva, vol. I, Porto, Faculdade de Letras, 1972.

(101) Vitorino Nemésio, A mocidade de Herculano até à volta do exílio (1810-1832), Lisboa, Livraria Bertrand, 1934. Publicou também Exilados (1828-1832), História sentimental e politica do liberalismo na emigração, Lisboa, Bertrand, s.d., Ofélia Paiva Monteiro, A formação de Almeida Garrett. Experiência e criação, Coimbra, Centro de Estudos Românicos, 1971.

(102) Recorde-se, por exemplo, a publicação em 1955 pelos «Acta 


\section{A Revolução Francesa no Ensino da História}

a mesma força, as limitações políticas, científicas e psicclógicas que se passaram na área de História, o que se pode explicar até pelo facto de se entender que os "grandes escritores», apesar de liberais, republicanos ou socialistas, constituíam verdadeiras "glórias nacionais», que o próprio Salazarismo se esforçava por integrar no seu património, depois de diluídos os aspectos «revolucionários».

Voltando outra vez ao ensino universitário da História, torna-se interessante, apesar do valor relativo dos dados apresentados $\left({ }^{103}\right)$, conhecer algumas conclusões de tipo estatístico a que chegámos, através de uma breve análise das dissertações de licenciatura apresentadas nas Faculdades de Letras de Lisbca, Coimbra e Porto, procurando, sobretudo, captar nos assuntos por elas estudados as incidências epocais e temáticas.

Concluímos que nas três escolas as dissertações sobre a época moderna constituem a quantidade mais volumosa (cerca de $50 \%$ ), verificando-se um número relativamente baixo de dissertações respeitantes à época contemporânea (valores que oscilarão entre 11 e 14\%). É também significativo o facto de ser substancialmente maior o número de dissertacões sobre a época medieval em Coimbra em confronto com Lisboa (mais de $20 \%$ para cerca de $10 \%$ ), o que denuncia o sentido acentuadamente medievalista dos estudcs conimbricenses. Pode também acrescentar-se que em Lisboa abundam as teses de história económica e relacionadas com a problemática da expansão, ao passo que em Coimbra se salientam, pelo seu número, as dissertações de história regional e local, com uma incidência demográfica depois dos anos 60 , mercê da influência exercida

Universitatis Conimbrigensis" da obra de Joaquim de Carvalho, Estudos sobre a cultura portuguesa do século XIX, vol. I (Antheriana).

(103) Compulsámos os catálogos de dissertações de licenciatura existentes nas Bibliotecas das Faculdades de Letras de Lisboa, Cormbra є Porto, detectando ali, no caso da primeira, mais de 300 teses de História elaboradas por estudantes de Histórico-Filosóficas e de História, perto de 500 no caso da segunda, produzidas por alunos das mesmas licenciaturas e também por alguns de Filosofia, e pouco mais de 6 dezenas no Porto, da autoria de estudantes de História (recorde se que a nova Faculdade de Letras do Porto é de 1962). Os números aqui expostos não significam que correspondam à totalidade das dissertações elaboradas, razão por que os apresentamos de forma aproximada, pois não há a garantia de que os catálogos sejam exaustivos. Por outro lado, é por vezes muito difícil incluir as dissertações em âmbitos cronológicos definidos, havendo, consoante os seus temas e conforme o que entendermos pelo balizamento das épocas, várias hipóteses de classificação e de agrupamento. Por estes e outros motivos, preferimos optar pelas "reflexões estatísticas". a incluir aqui uma "estatística", qu$\epsilon$ chegámos a preparar, por entender que os valores desta, por serem 
nesse domínio por António de Oliveira, verificando-se no Porto uma maior incidência na história eclesiástica. Finalmente, acrescentemos que se, como afirmámos, o número de teses sobre a época contemporânea é sensivelmente pouco significativo, ainda o é mais se tivermos em conta que os temas relacionados com a problemática liberal são menos expressivos (pouco mais co que $6 \%$ em Lisboa e Coimbra, sendo no caso do Porto uma percentagem bem mais insignificante). Deve além disso destacar-se que as dissertações sobre esta temática surgem em Coimbra, sobretudo a partir de meados da década de 60, mercê dos seminários sistemáticos criados por Silva Dias, sendo, no entanto, também de salientar que em Lisboa o aparecimento de tais temas é geralmente mais precoce, aparecendo neste contexto alguns dos trabalhos pioneiros sobre o liberalismo português, como são os casos das teses de Julião Soares Azevedo e Piteira Santos.

Logo, pode dizer-se que os estudos universitários começavam a abrir-se para a época contemporânea, quando em 1974 se verifica a revolução proporcionada pelo movimento do 25 de Abril. E uma abertura lenta e difícil, como sugerimos, mas que seria, em qualquer situação, irreversível. O Dicionário de História de Portugal, publicado de 1960 a 1971 pela direç̧ão de Joel Serrão, que agregara universtiários e não universitários, conferindo uma importância representativa aos estudos contemporâneos, como que confirmava «institucionalmente» o seu significado. Do mesmo modo, algumas publicações sobre temas de história liberal, surgidas nos inícios dos anos 70, no Seminário de Cultura Portuguesa da Universidade de Coimbra, por acção de Silva Dias e com o patrocínio do Instituto de Alta Cultura, comprovam a abertura «oficial» aos novos temas $\left({ }^{104}\right)$.

10. Com a revolução de 1974 verifica-se, como atrás se disse, numa primeira fase, um processo de marxização do ensino. Se nas Faculdades de Letras o esquema curricular do ensino da História é claramente influenciado pelo sistema marxista - História das Sociedades Esclavagistas, História das Sociedades Feudais, História do Pré-Capitalismo e do Capitalismo Comercial, História do Capitalismo Industrial e da Génese do Socialismo, História do Capitalismo Monopolista e do Socia-

mais precisos, poderiam apresentar, com a ilusão do rigor, resultados poico exactos.

(104) Da nossa autoria, Tradicionalismo e Contra-Revolução. $O$ pensamento e a accão de José da Gama e Castro, Coimbra, Faculdade de Letras, Seminário de Cultura Portuguesa 1973; José Eduardo Horta Correia, Liberalismo ie Catolicismo. O problema congreganista (1820- 


\section{A Revolução Francesa no Ensino da História}

lismo, são as designações das cadeiras que constituem a linha chave do curso de História em Coimbra, onde, numa concepção internacionalista, não têm lugar à parte as disciplinas de História de Portugal - verifica-se, no domínio do ensino secundário, de igual modo, uma tentativa de interpretação da História segundo concepções económico-sociais inspiradas no marxismo-leninismo. Isso é evidente nas directivas oficiais e nos manuais do ensino da História dos anos imediatamente posteriores a 74, não só no domínio das matérias programadas e da terminologia utilizada, como até da bibliografia aconselhada. Com efeito, para além de obras essencialmente historiográficas, eram muitas vezes referidas como bibliografia básica obras de Marx, de Lenine, de Mao Tsé-Tung, a par dos textos produzidos no âmbito da «revolução portuguesa», dentro e fora do contexto marxista (105). Como em todos os momentos de convulsão revolucionária, verifica-se afinal um processo de interrelacão mimética do Passado e do Presente. Nesse sentido, acentua-se também um movimento editorial de traducões das obras «vermelhas» sobre a Revolução, de carácter historiográfico relevante ou simples interpretacões histórico-ideológicas. Para citar exemplos refiramos a publicação em língua portuguesa de obras de Albert Soboul, Daniel Guérin. Roger Vaillant, Marianne Roth, a par de textos de Babeuf e de Saint-Just (108). A estas, porém, juntavam-se já textos de outro tipo, representativos de interpretações não marxistas, como o de François Furet $\left({ }^{107}\right)$.

Outras transformações significativas no ensino da História vão-se, porém, operar sobretudo depois de 78. Nos cursos universitários nota-se uma evidente desmarxização, à medida que é anexada uma estrutura polifacetada da História que se desdobra em diversos ângulos, o económico e o social, o institu-

-1823), idem, 1974; José Esteves Pereira, Silvestre Pinheiro Ferreira. O seu pensamento político, idem, 1974. Outras obras se seguiram, já depois de 74, embora elaboradas e planeada a sua publicação anos antes.

(105) Ver por exemplo, António do Carmo Reis, História. Revolução Urbana - Revolucão Industrial. $8 .^{\circ}$ ano de escolaridade, $90^{\circ}$ ano de escolaridade, Porto, Edicões ASA, s.d. [1977?], sobretudo, pp. 54 ss e 160.

(106) A. Soboul, A Revolução Francesa, Lisboa; Horizonte, 1979. (2 vols.): D. Guérin, A luta de classes em Franca na primeira República, 1793-1795, Lisboa, A Regra do Jogo, 1977; R. Vaillant e Ravmond Manévy. Um homem do povo na nevolução, Amadora, Editorial Fronteira, 1976; M. Roth, Liberdade, igualdade, fraternidade. A Grande Revolucão Francesa de 1789. Lisboa, Edições Avante, 1976; Graco Babeuf, $O$ tribuno do povo, Lisboa, Iniciativas Editoriais, 1977; Louis Antoine de Saint-Just, Discursos e relatórios. Lisboa, Estampa, 1975.

(107) F. Furet, Ensaios sobre a Revolução Francesa, Lisboa, A Regra do Jogo. 1978. 


\section{Revista de Historia das Ideias}

cional e o político, e o cultural e o mental. Por outro lado, vai verificar-se a reintrodução da História de Portugal, em certas Faculdades, como vimos, inexistente com estatuto de autonomia, bem assim como da História dos Descobrimentos e da Expansão Portuguesa ( $\left.{ }^{108}\right)$. Além disso, a divisão da história por séculos vem acentuar o significado dos estudos sobre períodos mais recentes, dado que se criam unidades disciplinares referentes concretamente ao período que vai do século XVIII ao século $\mathrm{XX}$.

Mas essa acentuação torna-se ainda, porventura, mais evidente e significativa no ensino secundário ${ }^{\left({ }^{109}\right)}$. Com efeito, ao nível do curso geral desapareceu também a divisão tradicional de «Idade Moderna» e "Idade Contemporânea», que foi substituída por grandes núcleos temáticos. No $80^{\circ}$ ano «O Antigo Regime e sua desagregação» inclui agora a Revolução Francesa, que é entendida como elemento importante no processo desagregador de uma estrutura que, na realidade, só é substituída por uma outra, "A Revolução e a Civilização Industriais», no século XIX. Esta ocupa ainda grande parte do estudo nesse ano, verificando-se no $9 .^{\circ}$ ano a leccionação de todo um programa referente à história do século $\mathrm{XX}$. Também no «curso complementar» se verifica, no âmbito da História de Portugal, uma relevância conferida aos estudos do "nosso tempo», pois, recentemente e pela primeira vez, concedeu-se um lugar próprio ao estudo da nossa história subsequente a 1820 , que passou a ser objecto único dos estudos do $110^{\circ}$ ano de «Humanísticas».

Portanto, a Revolução Francesa e o liberalismo português já não são temas tabus e, mais, passam a ser entendidos como momentos significativos da história, sem, todavia, assumirem o papel absoluto no sentido da viragem. Isso resulta afinal de uma visão estrutural e económica da História. A Revolução Francesa terá sido um elo na cadeia de desagregação da sociedade «feudal» de "Antigo Regime», mas não desenvolveu uma função singular na estruturação de uma "Civilização Industrial» ou de um «Capitalismo Industrial» (para empregar uma terminologia economicista). Fenómeno essencialmente político, mes-

(108) Cfr. Decreto n.o 53/78, de 31 de Maio. Deve salientar-se que em Coimbra a citada reforma está neste momento já sendo ultrapassada por uma outra, que continua a conferir à época contemporânea um valor destacado, passando a existir uma cadeira de "História da Época Contemporânea" e outra de "História Contemporânea de Portugal» (Cfr. Portaria n. 508/86, de 10 de Setembro, e Portaria n. $.^{\circ} 844 / 87$. de 28 de Oitubro).

(109) Recordemos - conforme dissemos na nota 2-aue estamos ainda a utilizar a expressão "ensino secundário» de acordo com a acepção anterior à nova «lei de bases», entendendo como tal os $7 .^{\circ}, 8 .^{\circ} \mathrm{e}$ 


\section{A Revolução Francesa no Ensino da História}

mo que se encare numa projecção social, ele foi sofrendo um processo de relativa desvalorização perante uma concepção historiográfica que continuava - embora em processo de desmarxização - a acentuar o «económico-social» em desprimor do «político». Os próprios programas que surgiram em 1980 no âmbito da cadeira de História do $10^{\circ}$ ano, depois transferidos mutatis mutantis para o $12 .^{\circ}$, são reveladores dessa tendência. Com efeito, de 14 temas propostos oficialmente, dos quais teriam cle ser leccionados 8, tendo 6 fixos e obrigatórios e os outros facultativos, também encontramos um referente à Revolução Francesa, "As Revoluções Inglesas do século XVIII e a Revolução Francesa de 1789 - estudo comparativo», mas a que, todavia, não é concedido o carácter de obrigatoriedade. Essa obrigatoriedade era sim dada a temas clássicos da «História Nova»: «Estados, sociedades e economias do Próximo Oriente entre a Revolução urbana (Eneolítico) e a sua difusão do ferro e do alfabeto», "A evolução das tendências longas da economia da Europa moderna», "A demografia do Antigo Regime e a família - século XVI-XVIII», «A evolução das tendências longas e das crises na economia do século XIX e XX até 1929...», "O Islame: o império otomano - sécula XV-XVII...» e «As civilizações negras africanas e as suas mudanças perante o mundo industrial e as lutas imperialistas...». Actualmente, como se disse, esta estrutura de ensino é ministrada, com algumas alterações, no 12. ano, e, para além de um tema fixo, "Introdução à História», em que os avanços da «História Nova» ocupam um lugar fundamental, assumindo a leccionação quase o carácter de defesa intransigente da sua ideologia científica, são ainda ensinados mais três temas dos acima referidos - o segundo, o terceiro e o quarto.

Esta perda de força do tema da Revolução Francesa, ligada em parte ao desprestígio da «história política», que todavia está em vias de inversão, foi, pois, substituída pela importância adquirida por novos temas, não tão directamente ligados à França, em termos de realidade histórica, mas todavia bem relacionados com ela em termos de metodologia e ideologia científicas. Mas o certo é que as tendências para os estudos «contemporâneos»s se libertam cada vez mais dessa marca francófila, à medida que se desenvolvem. $O$ estudo da história portuguesa do século XIX e mesmo do século XX torna-se hoje, cada vez mais, um vector fundamental da nossa historiografia e, assim, não se poderá dizer que um colóquio sobre «A Revolução

9. anos (geral) e o $100^{\circ}$ e $110^{\circ}$ anos (complementar), considerando o $12 .^{\circ}$ ano como uma estrutura à parte, de tipo para-universitário. 
Francesa e a Península Ibérica», integrado no Bicentenário da Grande Revolução, possa ser entendido como um simples fenómeno precipitado de uma influência cultural francesa determinante. No seguimento de outros grandes colóquios sobre o século XIX - um realizado em 1979 por acção do Gabinete de Investigações Sociais («O século XIX em Portugal») e outro ocorrido em 1981 pelo Centro de Estudos de História Contemporânea Portuguesa ( $\mathrm{O}$ Liberalismo na Península Ibérica na primeira metade do século XIX») - e na continuação do colóquio realizado em Madrid em 1986 com idêntica designação do presente, procurou-se fundamentalmente analisar a situação portuguesa e ibérica, que tem a sua tipicidade, ainda que no contexto das eventuais influências francesas da Revolução. Num tempo em que continuam a ser traduzidos textos históricos sobre o grande fenómeno que indubitavelmente foi a Revolução Francesa (é o caso da recente tradução da obra de Michel Vovelle) (110), num momento em que se multiplica o movimento editorial português relativamente à nossa realidade liberal, ao nível de artigos de revistas, de obras historiográficas e de fontes, numa altura em que a Universidade aposta decididamente nos estudos contemporâneos - é evidente a quantidade de provas universitárias que se realizam sobre a temática liberal e até sobre problemas mais recentes -, numa época em que cada vez se procura mais (numa tendência também exagerada?) encaminhar o ensino básico e secundário para o ensino da história dos tempos próximos ${ }^{(111)}$, os estudos sobre a Revolução Francesa em Portugal já não são encarados tanto no contexto da realidade da França, mas sim no âmbito da nossa própria realidade. Não se trata, pois, tanto de estudar a Revolução Francesa e a Península Ibérica, mas a Península Ibérica e a Revolução Francesa. A inversão dos termos, no contexto do título deste colóquio, apenas se deve a uma prioridade cronológica da Grande Revolução.

11. Eis, pois, em linhas gerais e sem dúvida lacunares e provisórias, a primeira tentativa de estudar o lugar que a Revolução Francesa teve no temário e no tratamento do ensino

(110) A mentalidade revolucionária. Sociedade e mentalidades na Revolucão Francesa, Lisboa, Salamandra, 1987.

(111) Na recente Proposta de reorganização dos planos curriculares dos ensinos básico e secundário, da autoria de J.J.R. Fraústo da Silva (coordenador), Roberto Carneiro, Manuel Tavares Emídio e Eduardo Marçal Grilo, Novembro de 1987, pode verificar-se que nos conteúdos gerais programáticos referentes à disciplina de "Ciências Humanas e Sociais» - que, no actual $30^{\circ}$ ciclo do ensino básico $\left(70^{\circ}, 8^{\circ} \mathrm{e}\right.$ 
da História em Portugal. Como vimos, ela passou de um fenómeno entendido como marginal, por razões de natureza política, a um fenómeno considerado fundamental mas não nuclear, por razões de natureza científica ou ideológico-científica. As crises de identidade nacional, as crises de identidade política dos vários sectores ideológicos, as encruzilhadas epistemológicas da História e as dúvidas sobre os rumos do seu ensino, explicam, em grande parte, os afastamentos e as aproximações em relação à Revolução Francesa. E um processo complexo, como vimos, que se tornará cada vez mais complexo à medida que o formos aprofundando.

9. anos), substitui as cadeiras de Geografia e História e alarga o seu âmbito - se salienta que o estudo da "história das civilizações» deve relevar a «época contemporânea» (p. 73). 